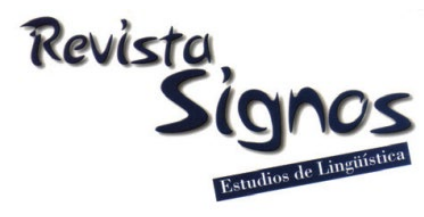

\title{
Register cartography and Giovanni Parodi's research: Registerial profiles of school subjects and university disciplines
}

\section{La cartografía registral y la investigación de Giovanni Parodi: Perfiles registrales de asignaturas escolares y disciplinas universitarias}

\author{
Christian M.I.M. Matthiessen \\ HUNAN UNIVERSITY \\ CHINA \\ cmatthie@icloud.com
}

Recibido: 21-VII-2021 / Aceptado: 04-XI-2021

DOI: $10.4067 /$ S0718-09342021000300799

\begin{abstract}
In this article, I explore the functional varieties of language, i.e. registers (or genres), used in different school subjects and university disciplines, examining the ranges of registers used in a selection of subjects and disciplines - their registerial profiles. I draw on Giovanni Parodi's research into registerial profiles of university disciplines and on systemic functional work on registerial profiles of school subjects, showing how they complement one another. I sketch an outline of a comprehensive view informed by these pioneering contributions so that future research can fill in gaps and further illuminate registerial profiles of different fields of study, curricular composition and sequence of registers and learner paths through institutions of education seen in terms of expanding personal registerial repertoires. For the sake of conceptual clarification, I also touch on different approaches to the phenomenon of functional variation within language according contexts of use under the headings of 'register' and 'genre'.
\end{abstract}

Key Words: Register, registerial profile, discourse genre, systemic functional linguistics, school subject, university discipline.

\section{Resumen}

En este artículo, exploro las variedades funcionales del lenguaje, es decir, los registros (o géneros), utilizados en diferentes asignaturas escolares y disciplinas universitarias, examinando las gamas de registros utilizados en una selección de asignaturas y disciplinas: 
sus perfiles registrales. Me baso en la investigación de Giovanni Parodi sobre los perfiles de registro de las disciplinas universitarias y en el trabajo sistémico funcional sobre los perfiles de registro de las asignaturas escolares, mostrando cómo se complementan entre sí. Esbozo una visión global basada en estas contribuciones pioneras, de modo que la investigación futura pueda llenar los vacíos existentes e iluminar aún más los perfiles de registro de los diferentes campos de estudio, la composición curricular y la secuencia de registros, así como las trayectorias de los alumnos a través de las instituciones educativas, vistas en términos de expansión de los repertorios de registro personales. A efectos de clarificación conceptual, también me refiero a diferentes enfoques del fenómeno de la variación funcional dentro de la lengua según los contextos de uso, bajo los conceptos de 'registro' y 'género'.

Palabras Clave: Registro, perfil registral, género discursivo, lingüística funcional sistémica, asignatura escolar, disciplina universitaria.

\section{INTRODUCTION}

Giovanni Parodi's scholarship is wide, deep and very rich, and I have learned from many aspects of his work - and also found in him a brilliant model for scholarship in general and linguistics in particular. I've been very fortunate that he has been a wonderful friend and inspiring long-distance colleague. I have benefitted greatly from detailed discussion with him in Chile, Hong Kong, Canada and Germany.

Here I will focus on what I see as a long-term research programme into discourse genres in different university disciplines and workplaces undertaken by him and his group, and reported on by them in Parodi (2010a) ${ }^{1}$. I will interpret discourse genres as registers, and I will view the research programme in terms of my notion of registerial cartography - i.e. of identifying and describing registers (functional varieties), or 'genres', of language in terms of the contexts that they are used in and in terms of their linguistic features (e.g. Matthiessen, 1993, 2015a, 2019)2 ${ }^{2}$. More specifically, I will consider the registerial make-up of different school subjects, drawing on the work in Systemic Functional Linguistics presented by Christie and Derewianka (2008) and examples of studies of specific school subjects, and then move on to the registerial make-up of university disciplines, drawing on the pioneering work presented by Parodi (2010a), a contribution that also sheds light on post-university workplace registers (although I won't have space here to draw on that aspect of their research).

This review of different contributions can be seen in the context a programme for mapping out the registerial make-up of different subject and disciplines, and also, importantly, in the context of investigating our semiotic lifelines — our progression through life as involving expanding our own registerial repertoires (the registers, or 'genres', that we master as we go through life) so as to enable us to take on new institutional roles and engaging in new fields of activity ${ }^{3}$. I have represented key features of this progression in terms of a person's lifeline from infancy to late adolescence, with anticipation of early adulthood onwards as Figure 1 (for further discussion, see e.g. 
Matthiessen \& Teruya, forthcoming). The Figure is arranged left to right to indicate progression through time in different phases, and the vertical axis represents the expansion of our linguistics (and other semiotic) resources.

The first phases are developments during infancy and early childhood. The study of these phases in SFL have been informed by Halliday's pioneering work on "learning how to mean" in the form of a longitudinal case study based on the diary method (Halliday, 1975: 2003). Subsequent studies include Painter $(1984,1999)$ and Torr (1997). The early childhood studies are reviewed by Torr (2015), Painter (2017). Halliday recognizes three phases: Phase I - protolanguage $>$ Phase II - transition from protolanguage to the mother tongue $>$ Phase III — the mother tongue.

Phase III continues throughout our semiotic lives. One important characteristic of Phase III is that we continue to expand our personal registerial repertoires as we meet new ranges of registers during formal education, in school subjects and in university disciplines, and then other institutions we take up roles in, importantly in workplaces. Systemic functional research into Phase III development has focussed on institutions of formal education, to a large extent on the development of writing and the registers (genres). (Here students may also experience linguistic tensions due to semantic variation of the codal kind: depending on the coding orientation that they have grown up with, it may or may not resonate with the coding orientation of their teachers and the institution of formal education in general. This has of course been a major focus in the developments in SFL based on the dialogue with Basil Bernstein initiated in the 1960s: see e.g. Bernstein, 1971; Hasan, 1973, 2009; Halliday, 1978, 1994; Macken-Horarik, 2006.) For a summary of the systemic functional research that covers both the early childhood studies and the school-based studies (primary and secondary), see McCabe (2021), and for a summary of linguistic features throughout primary and secondary school, see Christie and Derewianka (2008). Importantly, Derewianka (1995) has undertaken one longitudinal case study of one child gradually mastering ideational grammatical metaphor in the course of learning how to mean through writing.

When we turn to continued Phase III development beyond late adolescence in secondary school, there is as yet no comparable body of work in SFL (but, for some references, see Gardner, 2017; and for register analysis of disciplinarity, see Teich, Degaetano-Ortlieb, Fankhauser, Kermes \& Lapshinova-Koltunski, 2016). However, this is precisely where Parodi (2010a) comes to the rescue, including the identification of the registerial (genre) ranges of different university disciplines.

(At any point in language development, learners may engage with additional languages; but I will not discuss multilinguality here (e.g. Matthiessen, 2018), nor second/ foreign language education (see Byrnes, 2019).) Significantly, the expansion of 
learners' registerial repertoires is boosted in secondary school and as they move through their undergraduate university disciplinary degrees, they learn the registers of spoken and written academic discourse. As students move through the educational system, they gradually master new registers, adding them to their personal registerial repertoires, which means that can also take on an increasing range of roles in new contextual settings. Thus as they accumulate registers, their meaning potentials grow. This will, of course, continue into life beyond their journeys through institutions of education. Importantly, students continue to learn how to mean throughout their school years, which includes lexicogrammar. For example, the relational lexicogrammar of proof is a fairly late development. For a detailed summary of examples of 'major features in writing in' in different subjects 'from early childhood to late adolescence', see Christie and Derewianka (2008), and for details in writing English, history, science, see Christie and Derewianka (2008).

A key insight emerging both from Christie and Derewianka (2008) and from Parodi (2010a) is that registerial ranges vary considerably from one school subject to another and from one university discipline to another; they are characterized by different registerial profiles. We can relate this to the knowledge structures (ideational meanings) that characterize different subjects and disciplines - e.g. whether they are developed vertically or horizontally (Bernstein, 2000); but of course, other aspect of the total semiotic construction of different subjects and disciplines are also of crucial importance, e.g. what is given value in a given subject or discipline - say history vs. science. 


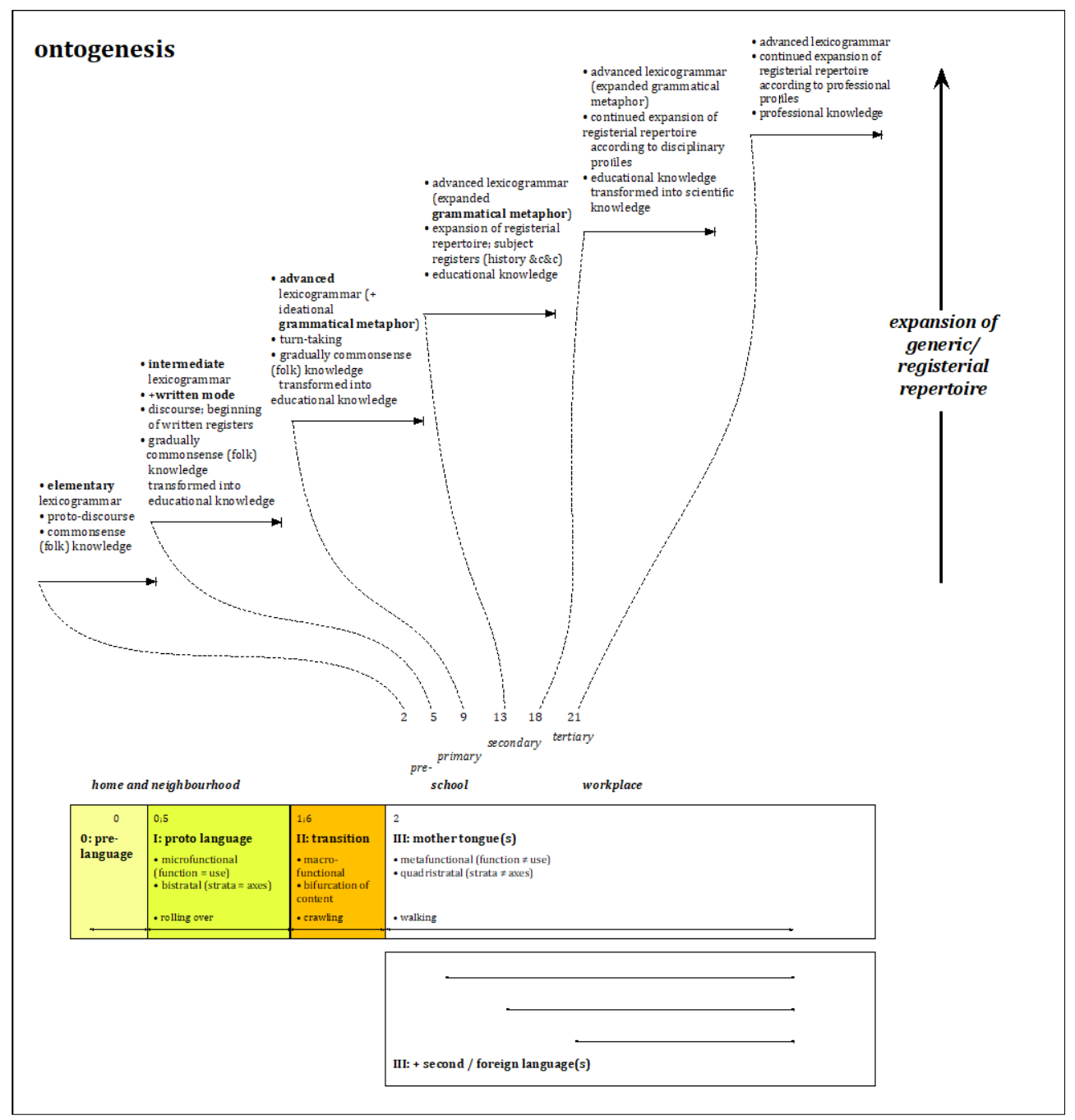

Figure 1. Ontogenetic progression - learning how to mean, and the expansion of the meaning potential.

In the remainder of this paper, I will first introduce the notion of registerial cartography (Section 1) — just enough to get on with the task at hand, outlining maps of registers, or 'discourse genres', in different school subjects and university disciplines. I will then review and interpret the research on 'school discourse', based largely on Australian studies, in terms of registerial cartography (Section 2). These two sections lead to my characterization of Parodi (2010a) in terms of registerial cartography (Section 3), where I also complement this pioneering study with a brief account of comparable patterns emerging in the British Academic Witten English corpus. In the conclusion, I try to bring out motifs that can be discerned in these studies. 


\section{Registerial cartography}

The project of registerial cartography (Matthiessen, 2015a) is a long-term effort undertaken to characterize registers fully — in the round, as it were (trinocularly), and to identify the registers operating in particular institutions or institutional settings like tea breaks at a workplace (Eggins \& Slade, 2005) or the emergency department of a large hospital (Slade, Manidis, McGregor, Scheeres, Chandler, Stein-Parbury, Dunstan, Herke \& Matthiessen, 2015). Most work in SFL has almost certainly been done within J.R. Martin's Sydney School, using the 'genre model' (Rose \& Martin, 2012), on registers in education, in particular up through secondary school (Christie \& Martin, 1997; Coffin, 2006; Christie \& Derewianka, 2008; Martin \& Rose, 2008), but institutions other than that of education have also been mapped (Iedema, Feez \& White, 1994). This descriptive body of work can be related to the description of context that I will sketch here and then also use to interpret the disciplinary genre distributions documented by Parodi (2010a).

\subsection{Registers as functional varieties of language in contexts of use}

A register is, as noted above, a functional variety of language associated with some particular contextual setting - more technically, with an institutional domain or generalized situation type (for early characterizations, see Halliday, McIntosh \& Strevens, 1964; Gregory, 1967; Hasan, 1973; Ure \& Ellis, 1977). From the point of view of language as a meaning potential, a register is a sub-meaning potential — the meanings 'at risk' in the institutional domain that it operates in (e.g. Halliday, 1978); it constitutes the semantic strategies deployed in that institutional domain to pursue the contextual goals (as illustrated by Halliday's, 1972, description of maternal regulatory semantics, and modelled computationally by Patten, 1988, within the AI paradigm of problem solving). It thus makes functional sense to characterize registers in the first instance 'from above'4, from the vantage point of context in terms of the settings of the parameters of the institutional domain that it operates in (Matthiessen, 2019).

But part of the description of a register is to relate its contextual matrix to the view 'from below' in terms of the lexicogrammatical patterns that realize the meanings of the registers and, by another stratal step, the phonological or graphological patterns (cf. Figure 3, to be discussed below). However, we also need to characterize a given register 'from roundabout' - from its own level of semantics as strategic options in meaning. ${ }^{5}$

As just noted, the approach to register as contextually conditioned functional variation prioritizes the view 'from above', from the point of view of context. This approach to register is thus ecological in nature; we investigate the 'meanings at risk' in different registers by characterizing the contexts in which they operate, i.e. their semiotic environments. Contexts are multi-dimensional, but since Halliday et al. (1964) these dimensions have been theorized in SFL in terms of three primary contextual 
parameters, now known as field, tenor and mode (Halliday, 1978). Each of them covers more than one sub-parameter, but we can represent these primary parameters as defining the overall contextual space within which we can identify and describe register variation in language: see Figure 2. The multidimensional contextual space in which register variation occurs is, clearly, not static; it is always evolving. Thus as contextual needs change in the culture of a community, new registers will emerge gradually and evolve and also change the context since they provide new modes of meaning, as happened in the case of the register of scientific discourse (Halliday, 1988) and in the case of the register of news reports (Nanri, 1993)' disappear when the contexts in which they operate fade away. Languages are made up of registers, their functional varieties; they are aggregates or assemblages of registers (e.g. Halliday, 1978; Matthiessen, 2015a, 2019). For this reason, languages are adaptive systems - they adapt to contextual conditions; but while particular registers may have lifespans, languages continue to evolve through their dynamic registerial make-up unless they encounter catastrophic conditions as will happen in the course of colonization.

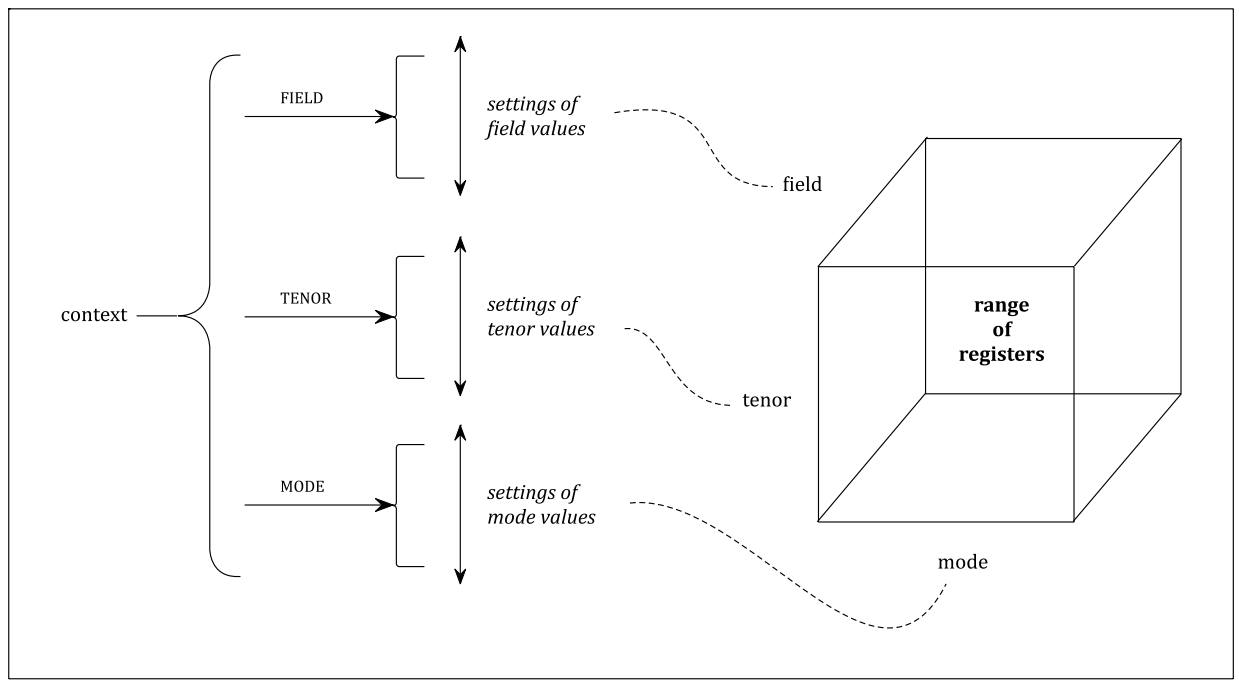

Figure 2. The fundamental parameters of context (the semiotic environment in which language operates): Field, tenor and mode.

\subsection{The location of register variation in terms of instantiation and stratification}

To recap: a register is a functional variety of language associated with a context of use, as shown in Figure 2, which is organized in terms of the two semiotic dimensions of stratification and instantiation (the stratification-instantiation matrix; see e.g. Halliday, 2002). 
(i) In terms of the stratification of language in context, a register is a semantic variety in the first instance - the meanings at risk in that context of use, the part of the overall meaning potential of the language deployed within that context of use. But since semantics is related by realization to the lower strata of language, and since the relationship between semantics and lexicogrammar as the two strata of the content plane is a natural one, the meanings at risk are realized as wordings at risk within lexicogrammar, and by another stratal step, by the phonological or graphological patterns at risk, but this step is less direct since the relationship between lexicogrammar and phonology / graphology within the expression plane is a largely conventional rather than natural one. (However, certain expression features may be indexical of particular registers, like the rhythmic patterns of news reading - see Martinec, 2018, prosodic patterns of rap — see Caldwell, 2014, of sports commentators - see Bowcher, 2003, or of auctioneering.)

(ii) In terms of the cline of instantiation, a register is an intermediate region between the potential pole of the cline, language as system, and the instantial pole, language as text; and it is associated with the same intermediate region within context, between the context of culture at the potential pole of the cline of instantiation, the cultural potential of a community, and contexts of situation at the instance pole (cf. Halliday, 1991). If we approach the intermediate region along the cline of instantiation from the potential pole, we can view the patterns as functional varieties of the language - as sub-meaning potentials adapted to contextual settings within particular institutions, i.e. as registers; and if we approach it from the instance pole, we can interpret them inductively as types of texts that emerge in the course of repeated instantiations of the linguistic system.

Figure 3 thus represents the phenomena we study under the heading of registerial cartography - the long-term research programme to identity and describe functional varieties of language in their contexts of use. One important example would be the project documented by Parodi (2010a): the registerial map of four different disciplines in an institution of higher learning, identifying the registerial range of each discipline. 


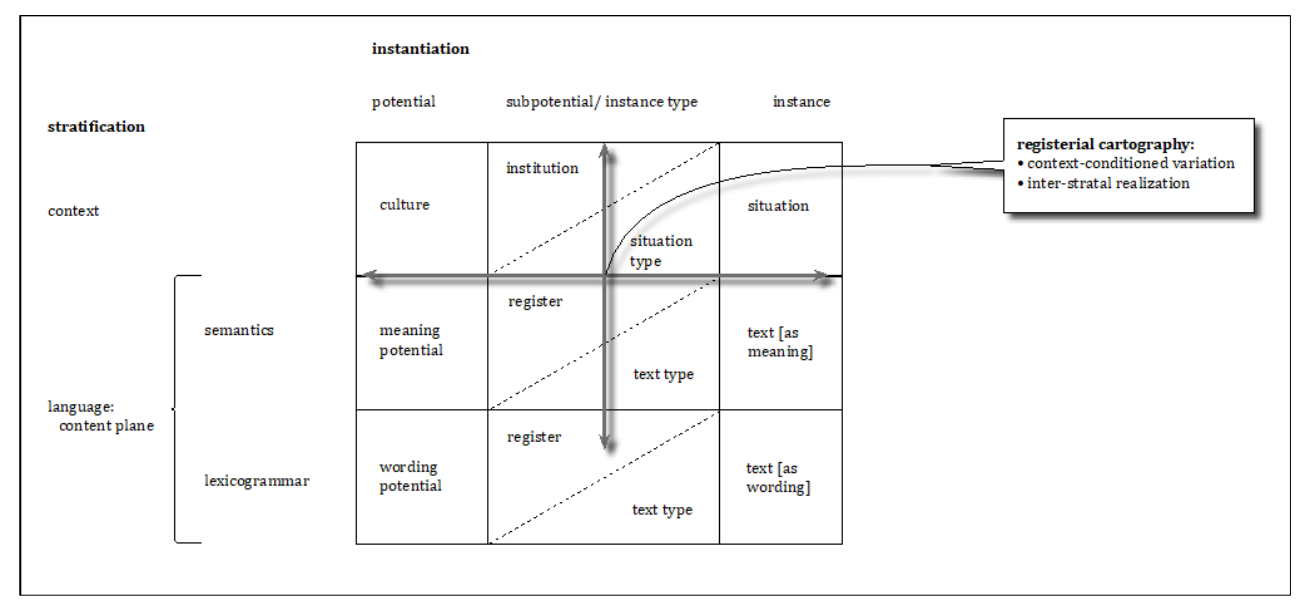

Figure 3. The location of register and register variation along the cline of instantiation and the hierarchy of stratification, and thus the focus of investigation in registerial cartography.

\subsection{Contextual parameters: Field, tenor and mode and Parodi's 'criteria and variables that classify genre'}

Returning now to the semiotic space within context defined by field, tenor and mode in Figure 2. I will identify the correspondences between these and Parodi's 'criteria and variables that classify genre', but first I need to take one step further in delicacy. The contextual parameters of field, tenor and mode involve sub-parameters, which I have specified in Table 1 (see e.g. Halliday, 1978; Halliday \& Hasan, 1985; Martin, 1992; Wegener, 2011; Matthiessen, 2015a). While scholars have elaborated on field, tenor and mode and have suggested some alternatives, the primary parameters have remained quite stable since the 1960s (with rhetorical mode, or functional tenor, as an interesting exception: see e.g. Martin, 1992; Matthiessen, 2015b). 
Table 1. The contextual parameters of field, tenor and mode, with secondary parameters and examples indicating ranges of values of the parameters.

\begin{tabular}{|c|c|c|}
\hline $\begin{array}{l}\text { Primary } \\
\text { parameter }\end{array}$ & secondary parameter & examples \\
\hline \multirow[t]{2}{*}{ field } & field of activity & See Figure 3 \\
\hline & $\begin{array}{l}\text { Field of experience (domain of } \\
\text { knowledge, subject matter) }\end{array}$ & $\begin{array}{l}\text { the phenomenal realms of school subjects } \\
\text { and of university disciplines }\end{array}$ \\
\hline \multirow[t]{6}{*}{ tenor } & institutional roles & $\begin{array}{l}\text { parent-child, teacher-student, employer- } \\
\text { employee }\end{array}$ \\
\hline & status (power) roles & equal / unequal \\
\hline & contact roles & familiar / stranger \\
\hline & speech roles & $\begin{array}{l}\text { initiating / responding } \& \text { giving } / \\
\text { demanding ... }\end{array}$ \\
\hline & sociometric roles (affect) & neutral / charged \\
\hline & stance (towards field of experience) & neutral / loaded \\
\hline \multirow[t]{6}{*}{ mode } & medium & spoken / written \\
\hline & channel & $\begin{array}{l}\text { auditory / visual, and various combinations, } \\
\text { and technologies }\end{array}$ \\
\hline & turn & monologic / dialogic \\
\hline & division of semiotic labour & monomodal / multimodal \\
\hline & division of socio-semiotic labour & semiotic / social \\
\hline & rhetorical mode & $\begin{array}{l}\text { didactic / persuasive / diverting / } \\
\text { performative } \ldots\end{array}$ \\
\hline
\end{tabular}

Field, tenor and mode together determine the nature of the context in which a given register operates. For example, Halliday (1988: 140) characterizes scientific English as a "general functional variety, or register, of the modern English language" in terms of the context in which it operates:

"in field, extending, transmitting or exploring knowledge in the physical, biological or social sciences;

in tenor addressed to specialists, to learners or to laymen, from within the same group (e.g. specialist to specialist) or across groups (e.g. lecturer to students); and

in mode, phonic or graphic channel, most congruent (e.g. formal 'written language' with graphic channel) or less so (e.g. formal with phonic channel), and with variation in rhetorical function - expository, hortatory, polemic, imaginative and so on."

This contextual characterization is relevant to Halliday's own study of the evolution of scientific English, and also to studies of registers in university disciplines, importantly including Parodi (2010a). Parodi, Ibáñez and Venegas (2010) present a detailed exploration of the 'criteria and variables that classify genre' (Parodi, 2010c), and they then use them systematically to characterize the 29 academic 'discourse genres' that they have identified in the PUCV-2006 Corpus. I will return to the genres which they identify in Section 2.2., but here it will be helpful to show the correspondences between their 'criteria and variables' and sub-parameters within field, tenor and mode: see Table 2. 
In terms of field, their "discourse organization mode" can be interpreted as being concerned with different fields of activity. In SFL accounts, there is a certain degree of apparent indeterminacy between "field of activity" and "rhetorical mode" (Halliday's "rhetorical function" above), but they are in fact complementary views on the context in which a given register operates. Still, there is a potential connection between Parodi's (2010a) "communicative macro-purpose" and field of activity?.

In terms of tenor, Parodi et al. (2010) detail tenor relations between expert writers and readers of varying degrees of expertise under the heading of 'relationship between participants' (cf. Halliday above on specialists). I have interpreted these in terms of institutional role within tenor, but there are also, quite naturally, implications for the tenor parameter of power (status) since one source of power is expertise.

In terms of mode, the medium is fixed to written language. Their 'modality' corresponds to what I have called division of semiotic labour (e.g. Matthiessen, 2006), their 'communicative macro-purpose' corresponds to rhetorical mode (cf. the reference above also to field of activity), and "context of circulation" can be interpreted as a rich conception of channel (but also with implications for tenor relations).

Clearly much more can, and should, be said about the correspondences that I have suggested; but I hope that my sketch will suffice as helpful background for the discussion in Section 3. I also hope that the correspondences I have proposed will further illuminate context, bringing together two complementary approaches. 
Table 2. Correspondences between field, tenor and mode in SFL and the "criteria and variables that classify genre' identified and characterized by Parodi et al. (2010).

\begin{tabular}{|c|c|c|c|}
\hline \multicolumn{2}{|c|}{ contextual parameters in SFL } & \multirow{2}{*}{\multicolumn{2}{|c|}{$\begin{array}{l}\text { Parodi, Ibáñez \& Venegas (2010: 42): criteria and } \\
\text { variables }\end{array}$}} \\
\hline $\begin{array}{l}\text { primary } \\
\text { parameter }\end{array}$ & $\begin{array}{l}\text { secondary } \\
\text { parameter }\end{array}$ & & \\
\hline \multirow[t]{2}{*}{ field } & field of activity & narrative / argumentative / descriptive & $\begin{array}{l}\text { discourse } \\
\text { organization mode }\end{array}$ \\
\hline & $\begin{array}{lr}\text { field of } & \text { experience } \\
\text { (domain } & \text { of } \\
\text { knowledge, subject } \\
\text { matter) }\end{array}$ & & \\
\hline \multirow[t]{6}{*}{ tenor } & institutional roles & $\begin{array}{l}\text { expert writer- } \\
\text { expert reader / semi-lay reader / lay } \\
\text { reader // expert and semi-lay reader / } \\
\text { semi-lay and lay reader / expert, semi- } \\
\text { lay and lay reader }\end{array}$ & $\begin{array}{l}\text { relationship } \\
\text { between } \\
\text { participants }\end{array}$ \\
\hline & status (power) roles & & \\
\hline & contact roles & & \\
\hline & speech roles & & \\
\hline & $\begin{array}{l}\text { sociometric roles } \\
\text { (affect) }\end{array}$ & & \\
\hline & $\begin{array}{l}\text { stance (towards field } \\
\text { of experience) }\end{array}$ & & \\
\hline \multirow[t]{6}{*}{ mode } & medium & & \\
\hline & channel & $\begin{array}{l}\text { labour / universal / pedagogical / } \\
\text { scientific }\end{array}$ & $\begin{array}{l}\text { context } \\
\text { circulation }\end{array}$ \\
\hline & turn & & \\
\hline & $\begin{array}{l}\text { division of semiotic } \\
\text { labour }\end{array}$ & monomodal / multimodal & modality \\
\hline & $\begin{array}{l}\text { division of socio- } \\
\text { semiotic labour }\end{array}$ & & \\
\hline & rhetorical mode & $\begin{array}{l}\text { to instruct / consign / regulate / guide } \\
\text { / confirm / persuade / invite / offer }\end{array}$ & $\begin{array}{l}\text { communicative } \\
\text { macro-purpose }\end{array}$ \\
\hline
\end{tabular}

\subsection{Field: Field of activity (what's going on)}

Field, tenor and mode are all relevant to the characterization of the contexts in which registers operate - both the registers that make up school subjects and those that make up university disciplines. But in this paper, I will make use of a sub-parameter within field, field of activity, in particular. It will turn out to be useful in characterizing contextually the range of registers found in research on school subject and university disciplines, and certain aspects of tenor and mode are highly constrained in institutions of education, both schools and universities. Field of activity is one of the two field parameters; the other one, field of experience (subject matter), can be interpreting as reflecting the different domains of knowledge of school subjects and of university disciplines.

Field of activity is concerned with what is going on in context (Halliday, 1978) the socio-semiotic processes that people are engaged in. There have been several 
descriptive proposals within SFL (e.g. Martin, 1992; Hasan, 1999; Bowcher, 2007, 2014; Wegener, 2011). Here I will present a description a group of us have developed based on the (largely unpublished) work by Jean Ure (e.g. Matthiessen, 2009, 2015a; Matthiessen \& Teruya, 2016); my starting point was the manuscript of a book on discourse analysis she gave me in June 1989. In the current account, there are eight primary fields of activity, each being further differentiated into secondary fields of activity, as shown in Figure 4. This is a differentiation in delicacy, or 'granularity'; and it can be, and has been, further elaborated in delicacy. The primary and secondary fields of activity are characterized in Table 3 , where I have also added references to accounts of written registers given by Martin and Rose (2008) and spoken registers in casual conversation provided by Eggins and Slade (2005).

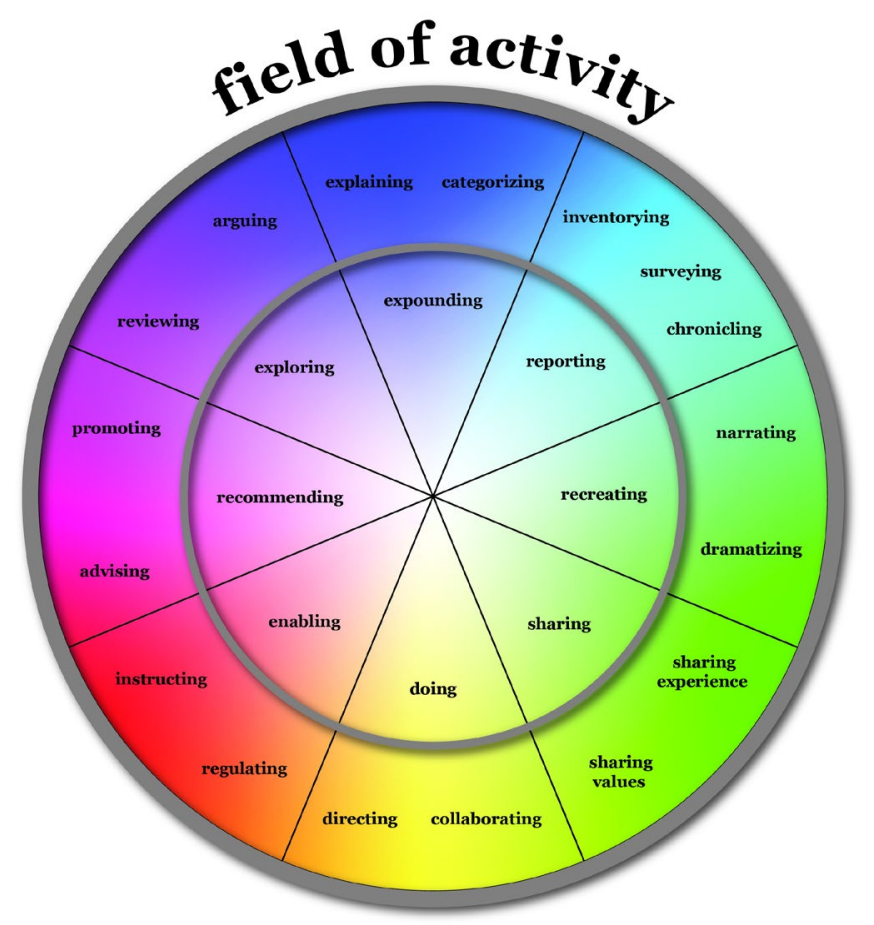

Figure 4. Context: Field of activity (socio-semiotic processes) within the contextual parameter of field. 
Table 3. Field of activity -primary and secondary types, with references to key publications within the SFL 'Genre Model'.

\begin{tabular}{|c|c|c|c|c|c|}
\hline \multicolumn{4}{|l|}{ field of activity } & \multicolumn{2}{|c|}{$\begin{array}{l}\text { Key accounts in the SFL literature based on the "Genre } \\
\text { model" }\end{array}$} \\
\hline primary type & characterization & secondary type & characterization & written: Martin \& Rose (2008): & $\begin{array}{l}\text { spoken: Eggins } \\
\text { \& Slade (2005) }\end{array}$ \\
\hline \multirow{2}{*}{ expounding } & \multirow[t]{2}{*}{$\begin{array}{l}\text { expounding our experience of classes of phenomena according to a general theory } \\
\text { (ranging from commonsense folk theories to uncommonsense scientific theories) }\end{array}$} & explaining & $\begin{array}{l}\text { explaining phenomena by specifying how they happen (temporal } \\
\text { sequence of events) or how they happen (causal sequence of events, } \\
\text { contributing factors) }\end{array}$ & $\begin{array}{l}\text { (Chapter } 4 \text { Reports and Explanations) } \\
\text { explanations }\end{array}$ & \\
\hline & & categorizing & $\begin{array}{l}\begin{array}{l}\text { categorizing (documenting) phenomena, by specifying their } \\
\text { properties, location in taxonomies and parts }\end{array} \\
\end{array}$ & $\begin{array}{l}\text { (Chapter } 4 \text { Reports and Explanations) } \\
\text { reports }\end{array}$ & \\
\hline \multirow[t]{3}{*}{ reporting } & \multirow[t]{3}{*}{$\begin{array}{l}\text { reporting on our experience of particular phenomena (as opposed to general classes } \\
\text { of phenomena) }\end{array}$} & chronicling & $\begin{array}{l}\text { chronicling the flow of particular events, linearly (as in historical } \\
\text { recounts, logbooks) - verbal timelines, or cyclically (as in modern } \\
\text { news reports) }\end{array}$ & $\begin{array}{llll}\text { Chapter } & 3 & \text { Histories) } & \text { recounts, } \\
\text { biographies } & & \\
\text { (Chapter } & 5 & \text { Procedures and } & \text { procedural } \\
\text { recounts) } & \text { procedural recounts } & \\
\end{array}$ & \\
\hline & & surveying & $\begin{array}{l}\text { surveying particular places — verbal maps (as in topographic } \\
\text { reports, e.g. in guidebooks) }\end{array}$ & & \\
\hline & & \begin{tabular}{|l|} 
inventorying \\
\end{tabular} & \begin{tabular}{|l|} 
inventorying particular entities (as in catalogues) \\
\end{tabular} & & \\
\hline recreating & $\begin{array}{l}\text { recreating our experience of the world imaginatively, that is, creating imaginaty } \\
\text { worlds having some direct or tenuous relation to the world of our daily lives - } \\
\text { through narration and/ or dramatization }\end{array}$ & $\begin{array}{l}\text { [narrating, } \\
\text { dramatizing] }\end{array}$ & & (Chapter 2 Stories) stories: narratives & \\
\hline sharing & $\begin{array}{l}\text { sharing our personal lives, prototypically in private, thereby establishing, } \\
\text { maintaining and negotiation personal relationships - sharing our personal } \\
\text { experiences and/ or sharing our personal values; }\end{array}$ & $\begin{array}{l}\text { [experiences, } \\
\text { values] }\end{array}$ & & $\begin{array}{l}\text { (Chapter } 2 \text { Stories) stories: anecdotes, } \\
\text { exempla }\end{array}$ & $\begin{array}{l}\text { chat; opinion, } \\
\text { teasing, gossip }\end{array}$ \\
\hline \multirow[t]{2}{*}{ doing } & \multirow[t]{2}{*}{$\begin{array}{l}\text { doing social activities, prototypically engaging in interactive social behaviour, } \\
\text { thereby collectively achieving some task }\end{array}$} & collaborating & $\begin{array}{l}\text { by members of one group collaborating with one another, using } \\
\text { language to coordinate their activities }\end{array}$ & & \\
\hline & & \begin{tabular}{|l|} 
directing \\
\end{tabular} & by one person directing the other members of a group & & \\
\hline \multirow{2}{*}{ recommending } & \multirow[t]{2}{*}{$\begin{array}{l}\text { recommending people to undertake some activity, thus very likely foreshadowing a } \\
\text { 'doing' context }\end{array}$} & promoting & $\begin{array}{l}\text { inducing them (promotion: recommendation for the benefit of the } \\
\text { speaker, as in consultations) }\end{array}$ & & \\
\hline & & advising & $\begin{array}{l}\text { by advising them (recommendation for the benefit of the } \\
\text { addressee, as in advertisements) }\end{array}$ & & \\
\hline \multirow[b]{2}{*}{ enabling } & \multirow[t]{2}{*}{$\begin{array}{l}\text { enabling people to undertake some activity, thus very likely foreshadowing a 'doing' } \\
\text { context }\end{array}$} & instructing & by instructing them in how to undertake the activity or & $\begin{array}{l}\text { (Chapter } 5 \text { Procedures and procedural } \\
\text { recounts) procedures }\end{array}$ & \\
\hline & & regulating & by regulating (controlling) their behaviour & $\begin{array}{l}\text { (Chapter } 5 \text { Procedures and procedural } \\
\text { recounts) protocols <or: embedded in } \\
\text { procedures }>\end{array}$ & \\
\hline \multirow[t]{3}{*}{ exploring } & \multirow[t]{3}{*}{$\begin{array}{l}\text { exploring our communal values and positions, prototypically in public (in contrast } \\
\text { with 'sharing') }\end{array}$} & arguing & \begin{tabular}{|l|} 
by arguing about positions and ideas \\
\end{tabular} & \begin{tabular}{lll|}
$\begin{array}{l}\text { (Chapter } 3 \\
\text { discussions }\end{array}$ & Histories) & expositions, \\
\end{tabular} & \\
\hline & & \begin{tabular}{|l|} 
reviewing \\
\end{tabular} & \begin{tabular}{|l} 
by reviewing a commodity (goods-- $\&$-services) \\
\end{tabular} & & \\
\hline & & rallying & $\begin{array}{l}\text { by rallying people around an idea or a cause (as in a political speech, } \\
\text { by members of the establishment or by protesters) }\end{array}$ & & \\
\hline
\end{tabular}


The representation of fields of activity in Figure 4 is topological in nature, which serves to bring out the indeterminacy inherent in the distinctions among the different fields of activity, as shown in Matthiessen and Teruya (2016). Referring among other publications to Martin and Matthiessen (1991), Parodi et al. (2010: 38) also highlight "the usefulness of the concept of topology (in opposition to typology)", noting "the gradation of a semiotic space". It is certainly possible to interpret the fields of activity shown in Figure 4 typologically by means of a system network; and this alternative account will invite decisions about the delicacy of distinctions among fields of activity - decisions that will shed further light on the account of the phenomena under description. Since these considerations do not affect the main issues explored here, I won't pursue them further (cf. Matthiessen, 2015a, in press).

\subsection{Summary}

In this section, I have presented the systemic functional interpretation of functional variation in language according to context, its semiotic environment, as register variation. I have also introduced a somewhat detailed description of one of the contextual parameters, field of activity, since I will use it in my discussion of registers in school subjects and university disciplines in the next two section. In addition, I have suggested the correspondences between the contextual parameters of field, tenor and mode in SFL and the 'criteria and variables that classify genre' used by Parodi and his team in their research into the distribution of registers, or 'discourse genres', in different university disciplines. This comparison has prepared the ground for the discussion in Section 3. But before I turn to the review there of the registerial cartography of university disciplines in that section, I will take the prior step of exploring the registerial cartography of school subjects.

\section{School discourse: Registerial cartography of school subjects}

In surveying contributions to the description of registers in different subjects in 'school discourse', I will rely on the research in systemic functional educational linguistics (for overviews, see Martin, 1985; Christie \& Martin, 1997; Schleppegrell, 2004; Martin \& Rose, 2008; Gardner, 2017; for detailed studies of the registerial makeup of particular subjects, see e.g. O'Halloran, 2005 [mathematics]; Coffin, 2006 [history]; Wignell, 2007 [social science]; Unsworth, 1995; Knain, 2015 [science]). This work includes an extensive and growing descriptive component, with accounts of the progression of language development through the school years - both the expansion of registerial ranges in particular and the growth of the overall meaning potential, as indicated in Figure 1 above, and also of the registerial ranges within different school subjects at different stages. I will start with registerial profiles of different subjects, based largely on studies of student writing — which will then relate directly to Parodi's (2010a) registerial profiles of four university disciplines, based on readings assigned to the 
students (Section 2.2.), and then give examples of progression through registers in curricular learner paths.

\subsection{Registerial profiles of different subjects}

In SFL, J.R. Martin and his team of colleagues and research students have identified and described registers of writing — or 'genres' in their 'Genre Model' — within educational linguistics for around our decades; this is sustained research programme, involving successive research projects (see Rose \& Martin, 2012, for a history of the programme; see also Gardner, 2017). Martin and Rose (2008) describe a number of the genres identified according to the genre families: stories, histories, reports and explanations, procedures and procedural recounts. They also note which subjects that particular genres are used in, and other contributions have foregrounded the registerial or generic profiling of different contributions.

In an early contribution, drawing on the SFL work in education through the early 1990s, Wignell (1994) discussed 'genre across the curriculum', showing the contrast between two subjects: 'characteristic sets of genres from two curriculum areas are chosen to provide a contrast in linguistic choices - technology and applied science and history'. Thus based on the research during the 1980s, it was clear already by the early 1990 s that school subjects had distinct and varied registerial profiles and that these profiles could be interpreted in terms of what it means to do history, science, and so on - the registerial repertoire somebody studying to become a historian would have to master, and so on. This is what I would regard as registerial cartography applied to the educational institution of schools (primary and secondary), with variation across the curriculum in terms of school subjects firmly in view. ${ }^{8}$

In a magnificent synthesis of genre-based research by themselves and other scholars, Christie and Derewianka (2008) document writing development in three school subjects, viz. English, history and science throughout the school years ${ }^{9}$. They selected these three subjects because they provide illuminating areas of contrast, illustrating how the same expanding meaning potential is deployed in different ways in the three subjects, with different registerial ranges. I have summarized their findings in Table 4, supplementing them with references to other overviews. The Table includes only those subjects they have selected, i.e. English, history and science, but not other school subjects whose registerial ranges have been documented (cf. the references at the beginning of this section).

I have organized the table in terms of one contextual variable, viz. field - more specifically field of activity (see Section 1 on registerial cartography), specifying two steps in delicacy in the first two columns. The next column specifies registers, i.e. functional varieties of language (and other semiotic systems), operating in contexts characterized by the different fields of activity. For example, recounts operate in contexts of reporting: chronicling. 
The next three columns are devoted to the three school subjects used as illustration, English, history and science. Very crudely, they can be interpreted as the other aspect of field, viz. field of experience, or domain of knowledge; but they differ contextually not only in terms of field, but also in terms of tenor and mode. For example, in terms of the value system of tenor, in science theory is given the most elevated value, so 'expounding' texts are foregrounded because they construe theory; but in humanities, represented here by English and history, value itself as manifested in arguments, interpretations and evaluations, is given the most elevated value, so 'exploring' texts are foregrounded because they enact value. Still, registerial differences among the three subjects reflect, to a considerable extent, differences in their domains of knowledge (the phenomena they are concerned with). However, the picture is dynamic rather than static - just like the evolution of science and scholarship of the last 500 years or so. And experts have advocated changes; thus against the background of traditional subject English, Christie and Macken-Horarik (2007) emphasize the need to build 'verticality in subject English', and Geoff Williams, Ruth French and other educational linguists have demonstrated the significance of introducing grammatics even in primary school (e.g. Williams, 2005; French, 2013; see also Schleppegrell, 2004). (During this period in history, the 'information' age, there is of course every reason why students should be empowered by theory construction and technicalization in their study of language since the information age is created through language in the first instance.) 
Table 4. The contextual parameter of field of activity associated registers with examples identified in three school subjects.

\begin{tabular}{|c|c|c|c|c|c|}
\hline \multirow{2}{*}{\multicolumn{2}{|c|}{$\begin{array}{l}\text { context } \\
\text { field of activity }\end{array}$}} & \multirow{3}{*}{$\begin{array}{l}\text { language } \\
\text { register } \\
\text { explanations } \\
\text { (sequential, } \\
\text { factorial, } \\
\text { conditional, } \\
\text { consequential) }\end{array}$} & \multicolumn{3}{|l|}{ school subject } \\
\hline & & & English & history & science \\
\hline \multirow[t]{2}{*}{ expounding } & explaining & & & $\begin{array}{l}\text { historical } \\
\text { explanations } \\
\text { (factorial, } \\
\text { consequential) }\end{array}$ & $\begin{array}{l}\text { scientific } \\
\text { explanations } \\
\text { (various) }\end{array}$ \\
\hline & characterizing & $\begin{array}{l}\text { reports } \\
\text { (descriptive, } \\
\text { taxonomic \&c) }\end{array}$ & & & $\begin{array}{l}\text { scientific } \\
\text { reports }\end{array}$ \\
\hline \multirow[t]{3}{*}{ reporting } & chronicling & recounts & recounts & $\begin{array}{l}\text { historical recounts, } \\
\text { biographies, } \\
\text { historical accounts }\end{array}$ & $\begin{array}{l}\text { procedural } \\
\text { recounts }\end{array}$ \\
\hline & surveying & $\begin{array}{l}\text { topographic } \\
\text { reports }\end{array}$ & & & \\
\hline & inventorying & & & & field studies? \\
\hline \multirow[t]{2}{*}{ recreating } & narrating & narratives & stories & (stories) & \\
\hline & dramatizing & plays & & & \\
\hline \multirow[t]{2}{*}{ sharing } & experiences & reminiscences & & & \\
\hline & opinions & $\begin{array}{l}\begin{array}{l}\text { opinion } \\
\text { gossip }\end{array} \\
\end{array}$ & $\begin{array}{l}\text { personal } \\
\text { responses }\end{array}$ & & \\
\hline \multirow[t]{2}{*}{ doing } & directing & & & & \\
\hline & collaborating & & & & \\
\hline \multirow[t]{2}{*}{ enabling } & regulating & $\begin{array}{l}\text { constitutions, } \\
\text { agreements }\end{array}$ & & & \\
\hline & instructing & $\begin{array}{l}\text { real-time } \\
\text { demonstrations }\end{array}$ & & demonstrations & \\
\hline \multirow[t]{2}{*}{ recommending } & advising & $\begin{array}{l}\text { advice columns, } \\
\text { professional } \\
\text { consultations }\end{array}$ & & & \\
\hline & promoting & advertisements & & & \\
\hline \multirow[t]{3}{*}{ exploring } & reviewing & reviews & reviews & & \\
\hline & rallying & $\begin{array}{l}\text { (political) } \\
\text { speeches }\end{array}$ & & & \\
\hline & arguing & $\begin{array}{l}\text { editorials; } \\
\text { expositions, } \\
\text { debates, } \\
\text { discussions }\end{array}$ & $\begin{array}{l}\text { literary } \\
\text { interpretations }\end{array}$ & $\begin{array}{l}\text { historical } \\
\text { interpretations, } \\
\text { analytical } \\
\text { expositions, } \\
\text { historiographical } \\
\text { expositions, } \\
\text { analytical } \\
\text { discussions, } \\
\text { challenges }\end{array}$ & $\begin{array}{l}\text { scientific } \\
\text { discussions }\end{array}$ \\
\hline references & & & $\begin{array}{l}\text { Christie \& } \\
\text { Derewianka } \\
(2008: \text { Chapters } \\
2 \text { \& 3); Christie } \\
\& \quad \text { Macken- } \\
\text { Horarik (2007) }\end{array}$ & 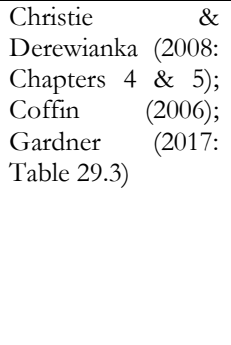 & $\begin{array}{lr}\text { Christie } & \text { \& } \\
\text { Derewianka } & \\
\text { (2008: Chapters } \\
6 \quad \& \quad & 7) ; \\
\text { Unsworth } & \\
(1995), & \text { Veel } \\
(1997), \quad \text { Pun } \\
(2011), \quad K \text { nain } \\
\text { (2015), } \\
\text { Matthiessen \& } \\
\text { Pun (2019) }\end{array}$ \\
\hline
\end{tabular}

The varied registerial profiles illustrated for English, history and science in Table 4 are characteristic of all subjects that have been investigated in SFL. Drawing on Pun's (2011) study of chemistry textbooks used in Hong Kong, I have used the fields of 
activity in a radial diagram to show the differences among English, history and science: see Figure 5. This visualization makes it easy to see that the semiotic centres of gravity for the three subjects are actually quite different. The centre of semiotic gravity in history is in 'reporting' - but as I will emphasize in the next subsection, there is a curricular progression from 'reporting' to 'expounding', and then to 'exploring'. In English, there are two centres of semiotic gravity, 'recreating' and 'exploring'. In view of the way that 'exploring' texts are valued, it is tempting to say that the centres are literature and meta-literature (cf. Lukin, 2003, on poetry and the literary criticism of poetry in schools): as verbal art, literature embodies a higher-order semiotic theme or motif (e.g. Hasan, 1985; Matthiessen, 2014, 2015c), and texts exploring verbal art similarly tend to their own themes, some kind of ideological stance on what is highly valued literature (typically changing over time, with periodic re-discoveries and reevaluations). In science (chemistry), the semiotic centre of gravity is 'expounding' this is where scientific theory is created; but the registers of science are complementary, representing different aspects of doing science (see immediately below).

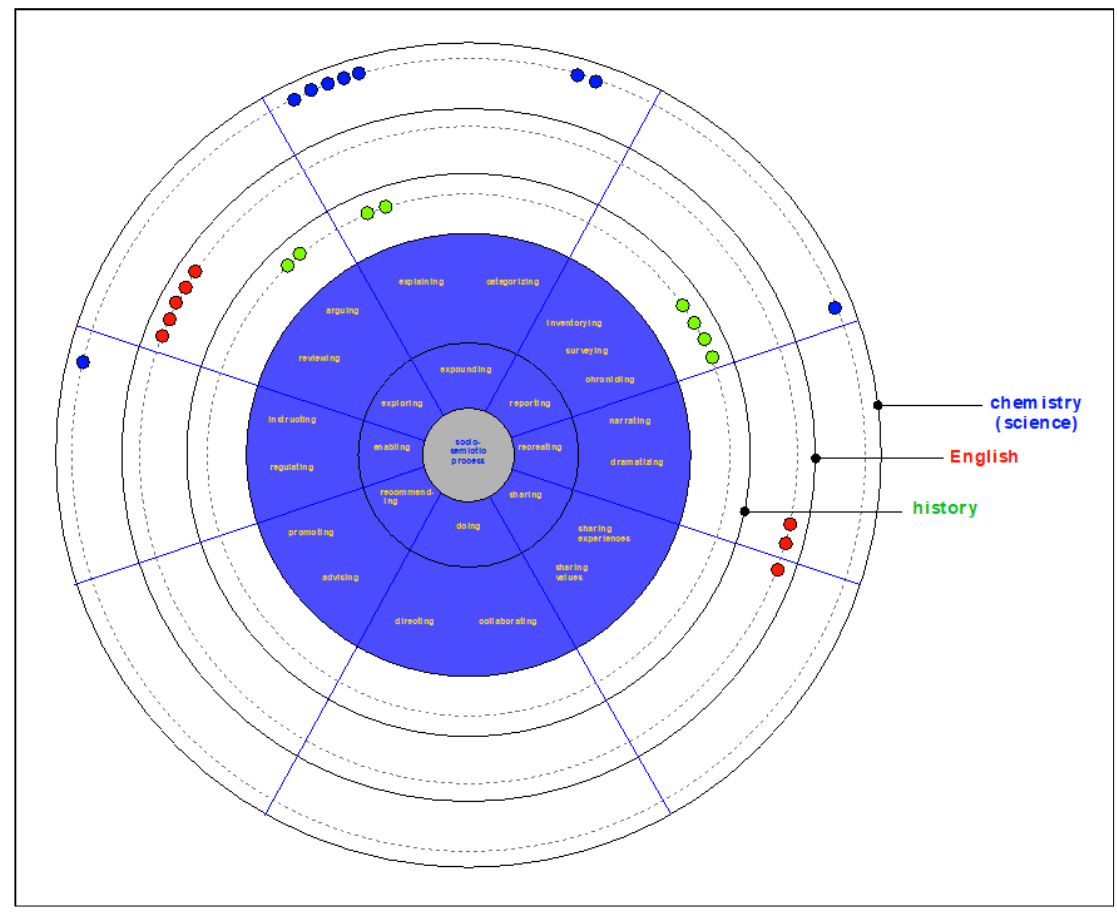

Figure 5. Registers in history (inner circle), English (middle circle) and science (chemistry; outer circle) operating in contexts characterized by different fields of activity.

In science, represented here by Pun's (2011) study of chemistry textbooks used in Hong Kong (for student writing in science, see Christie and Derewianka (2008): Chapters 6 and 7), the crowning achievement is the creation of scientific theory, which is an 'expounding' kind of activity. But this depends crucially on other fields of activity: 
reading texts in 'enabling' contexts, students prepare to carry out chemical experiments - experimental procedures, supported by regulations of behaviour in the lab. These are then executed in 'doing' contexts in the lab, where the students conduct chemical experiments. Here the mode is mostly spoken, so such texts are not included in textbooks. The experiments are reported in writing, in procedural recounts; the student record their findings, distilling the evidential base needed for the expounding of chemical theory. In addition, certain texts operate in the 'exploring' contexts; these are arguments about different chemical interpretations. (In Matthiessen \& Pun, 2019, we focus on the 'expounding: explaining' field of activity, including multimodal examples from chemistry.) Thus chemistry textbooks are macro-texts instantiating a macroregister of chemical science consisting of complementary registers. As already noted, there is further complementarity: in the spoken mode, students engage in lectures, group work, and lab experiments. 


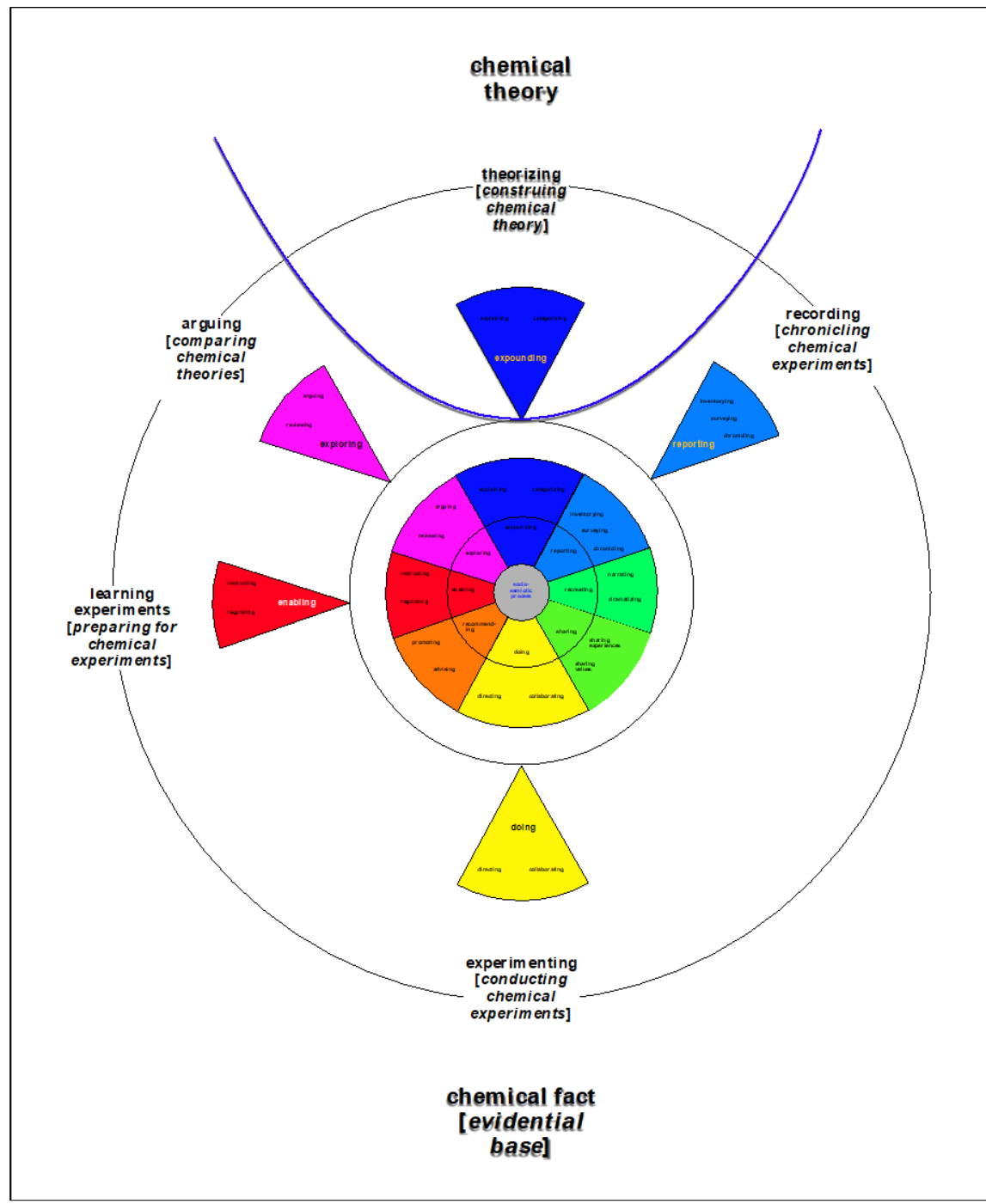

Figure 6. Doing - or meaning - chemistry: the complementary fields of activity that constitute chemistry (based on Pun, 2011); the segments crucial to chemistry are represented outside the radial map of fields of activity - doing, enabling, exploring, expounding and reporting.

\subsection{Progression from early childhood to late adolescence}

The registerial complementarity illustrated by chemistry in Figure 6 is essentially one of simultaneous registers. Although there will be a cycle through them for each topic in the textbooks and curriculum, they are all needed to engage with each topic. In contrast, there are other school subjects where there is a progression from one register to another through the school years. In subject history, different registers are involved, as shown in Figure 5; but there is a curricular progression from early primary school to late 
secondary school, creating a path for learners from stories to historiographical expositions. This registerial sequence is represented in Figure 7, which is based on the research documented by Coffin (2006) and Christie and Derewianka (2008); for additional discursive insights into, see also Martin and Rose (2008) and Martin and Wodak (2003). In my field-of-activity interpretation of their findings, the progression starts with simple sequence in time in the reporting segment — the time of events unfolding in history, in historical recounts and biographies. Then, in early secondary, cause is added in historical accounts, and by another step, in mid secondary, time is backgrounded and cause is foregrounded in historical explanations (factorial and consequential ones). Next, in mid secondary, the primary activity changes to exploring history in historical expositions and discussions, where cause is now internal cause (I/you believe proposition $\mathrm{m}$, because proposition $\mathrm{n}$ ) — evidence for claims about history - rather than the external cause of explanations (one event causing another: happening a, so happening b). This continues into late secondary, where in a sense history becomes meta-history — historiography, with historiographical expositions and discussions. In this way, doing history becomes increasingly discursive and virtual. The progression through registers is, of course, cumulative; and the registers are complementary aspects of doing history - but not like the successive topical cycles through the registers of chemistry in Figure 6. As in the case of other school subjects profiled registerially, it will be fascinating to find out what the registerial profiles of student writing in the comparable university disciplines turn out to look like (cf. Parodi, 2015, on seven university disciplines, including history and chemistry). This is clearly a very significant research question since in concerns the challenging transition for students who go on from high school to university programmes, where their apprenticeship as embryonic historians, chemists, mathematicians and so on will continue. 


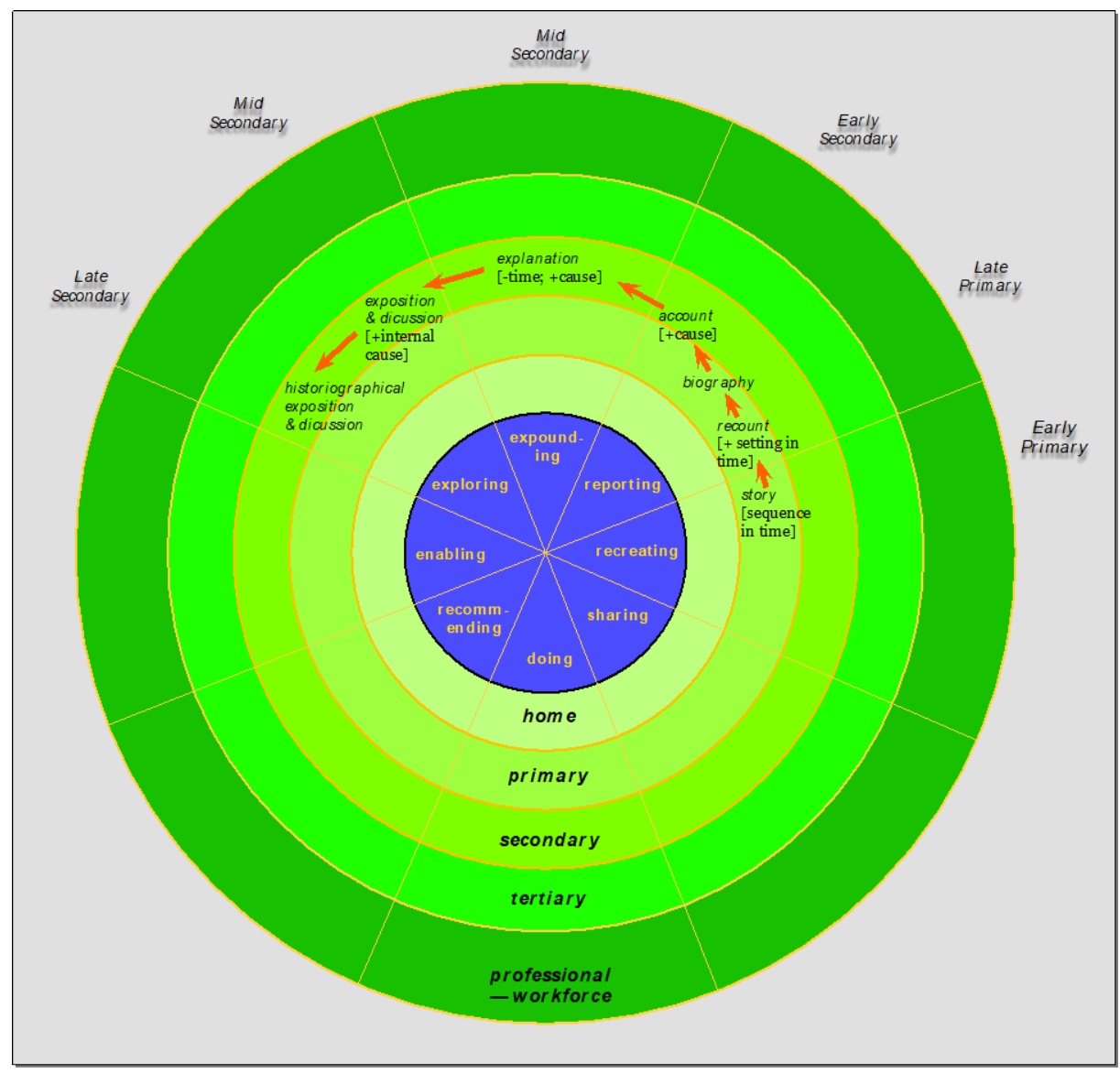

Figure 7. Learner path according to curricular progression in subject history.

\section{University discourse: Registerial cartography of university disciplines}

Moving to registerial profiles of university disciplines, I will now turn to the pioneering research documented and discussed by Giovanni Parodi and his team in Parodi (2010a), which is a tightly integrated volume he edited and provided key contributions to, including the theoretical framework underpinning their notion of 'discourse genre' (see Section 1 above).

\subsection{The PUCV-20o6 Corpus}

In drawing on their research, I'm switching from the focus in the SFL work on school discourse written by students to the reading material for students in the four undergraduate programmes investigated by Parodi and his team. Their corpus, PUCV2006 Corpus of Academic and Professional Spanish, is much larger than the corpora or text samples usually compiled in the SFL analysis of school discourse. It consists of 491 
texts, totalling almost 59 million words (e.g. Parodi, 2010b; Parodi et al., 2010). They selected four disciplines, two concerned with the realm of physical phenomena, viz. Industrial Chemistry and Construction Engineering, and two from the realms of biological and social phenomena, viz. Psychology and Social Work.

Just as the school subjects in Table 4 above (English, History and Science) can be roughly interpreted in terms of field of experience, or domains of knowledge, so these four disciplines can be, as indicated in Table $5^{10}$ (which also includes a column for the corpus of British Academic Written English [BAWE] to be discussed briefly below); but in both cases, the other contextual parameters are also relevant in characterizing the institutionalized subjects and disciplines, i.e. tenor and mode. For example, in terms of tenor, there are role relations and networks that are characteristic of disciplines involving teams in labs but not in traditional ways of undertaking work in the humanities - which is reflected in the number of authors per publication; and the tenor value systems of different subjects and disciplines can be significantly different.

Table 5. Fields of experience - the phenomenal realms - studied in school subjects analysed Christie and Derewianka (2008) and in university disciplines analysed in Parodi (2010a).

\begin{tabular}{|l|l|l|l|l|}
\hline \multicolumn{2}{|l|}{ systemic order } & school subject & $\begin{array}{l}\text { university } \\
\text { discipline } \\
\text { PUCV-2006 }\end{array}$ & $\begin{array}{l}\text { disciplinary } \\
\text { group in } \\
\text { BAWE }\end{array}$ \\
\hline \multirow{2}{*}{ immaterial } & $\begin{array}{l}\text { semiotic } \\
\text { ["cognitive"] }\end{array}$ & English, history & $\begin{array}{l}\text { arts and } \\
\text { humanities }\end{array}$ \\
\cline { 2 - 5 } & social & & Social Work & social sciences \\
\hline material & biological & & Psychology & life sciences \\
\cline { 2 - 5 } & physical & science & $\begin{array}{l}\text { Industrial } \\
\text { Chemistry, } \\
\text { Construction } \\
\text { Engineering }\end{array}$ & $\begin{array}{l}\text { physical } \\
\text { sciences }\end{array}$ \\
\hline
\end{tabular}

Parodi (2010e) provides the counts for the four different disciplines in terms of the number of texts and the number of words students must read. Using the percentages in his Table 3, I have created the chart in Figure 8. As Parodi notes, the differences in the volume of text students in the different disciplines are assigned to read are striking. In particular, the two physical disciplines, construction engineering and industrial chemistry, require much less reading than social work and psychology (but of course they are also spending their time engaged in other disciplinary activities). 


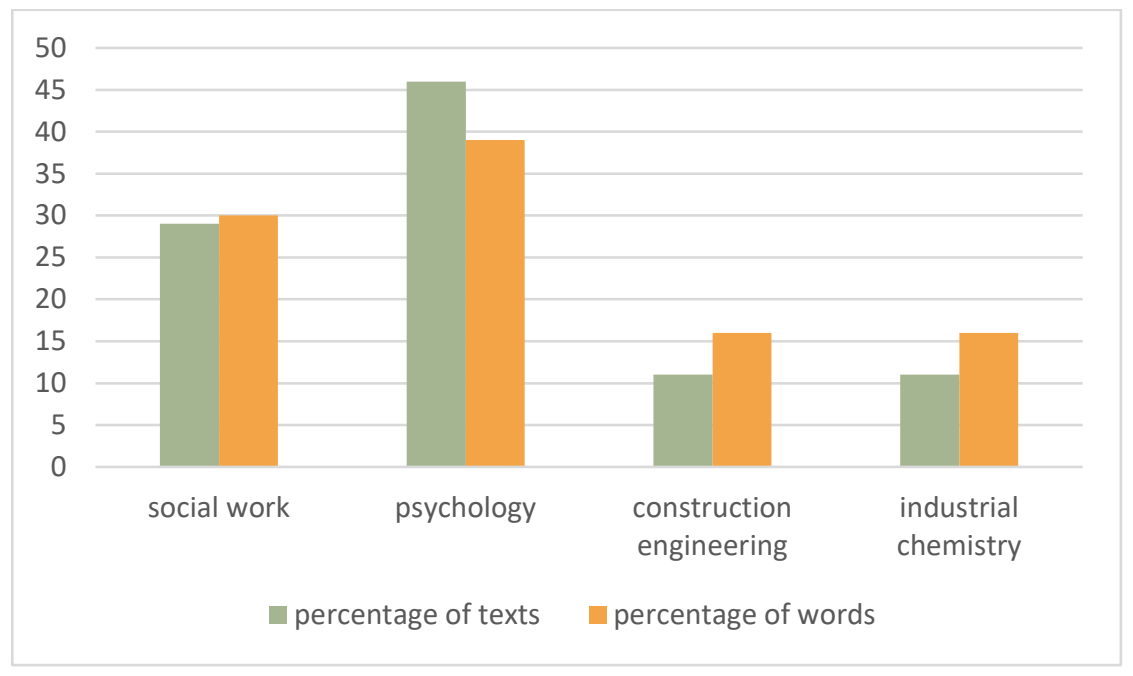

Figure 8. Volume of texts assigned in the four university disciplines investigated in Parodi (2010a) based on percentages in Parodi (2010e: 90)'s Table 3.

\subsection{Disciplinary profiles of ranges of registers ('disciplinary genres')}

In the university component of the PUCV-2006 corpus, Parodi et al. (2010: 47) identify 29 registers, or "discourse genres"11. Let me quote their characterizations of the ones that are most common across the four disciplines, viz. textbook (126 texts in the corpus), disciplinary text (270), didactic guideline (41 texts) (cf. Table 2 above on the interpretation of the properties they use in terms of field, tenor and mode):

Disciplinary Text: The communicative macro-purpose of this discourse genre is to persuade readers of one or more subject matters of a particular discipline. Ideally, the context of circulation is the scientific field, and the relationship between participants is between an expert writer and an expert or reader. Preferably, an argumentative mode of discourse organisation is used. Multimodal resources are also employed.

Textbook: The macro-purpose of this discourse genre is to instruct regarding concepts and/or procedures within a specialised subject matter. Its context of circulation is the pedagogical field, and the relationship between participants is between an expert writer and a semi-lay or lay reader. Preferably, a descriptive discourse organisation mode and multimodal resources are used.

Didactic Guideline: The communicative macro-purpose of this genre is to instruct about a specific disciplinary mat- ter and/or procedure. Its context of circulation is pedagogical, and the relation- ship between participants is between an expert writer and a semi-lay or lay reader. Preferably, an argumentative discourse organisation mode is used; and, occasionally, multimodal resources are employed. 
The next most common registers in terms of the number of texts are research article (22 texts), regulation (15 texts) and report (11 texts).

Building on the identification and characterization of discourse genres, Parodi (2010d) investigates their distribution across the four university disciplines and also the related workplace settings, and Parodi (2010e) concentrates on the university disciplines. He shows that the registerial profiles (in my terms ${ }^{12}$ ) are different for the four different disciplines, presenting the counts of registers for the disciplines on p. 94 in a column chart. To bring out the sense of the different disciplinary registerial profiles, I have re-represented his counts as a radial chart in Figure 9. As noted above, the most common registers overall are disciplinary texts, textbooks and didactic guidelines. However, they are not distributed evenly across the four disciplines. Textbooks are favoured by Industrial Chemistry and Construction Engineering, whereas Disciplinary Texts are favoured by Social Work and Psychology; and Didactic Guidelines occur mostly in Industrial Chemistry. Thus the disciplinary registerial profiles of the two physical sciences, Industrial Chemistry and Construction Engineering, are fairly similar, both favouring textbooks, and much more alike than the two non-physical sciences, Social Work and Psychology, which both favour disciplinary texts rather than textbooks.

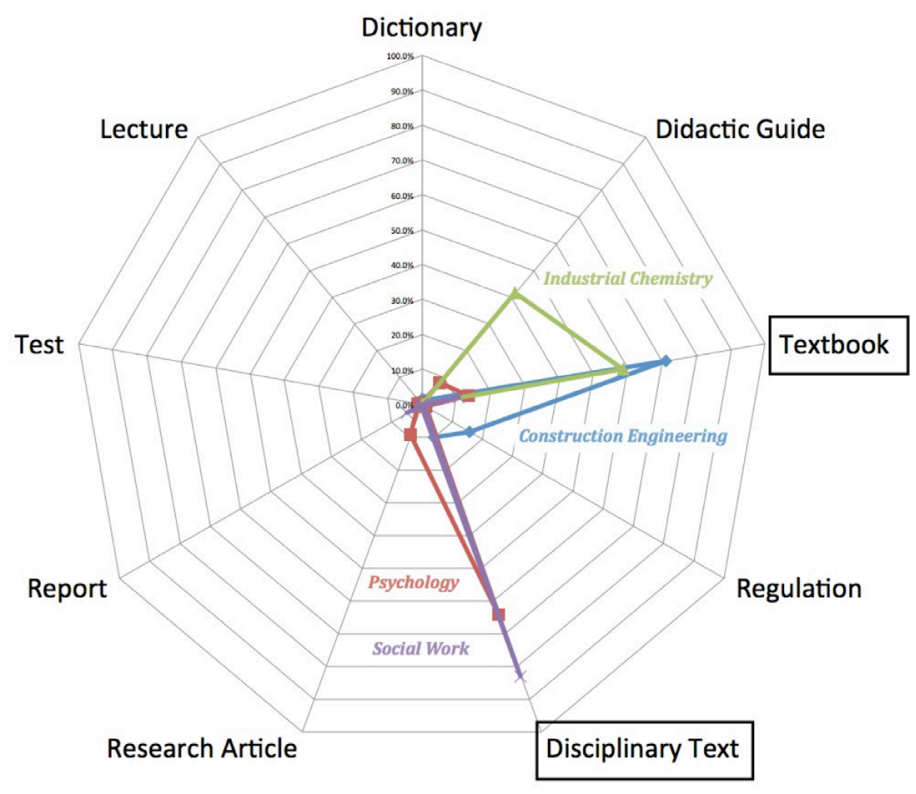

Figure 9. Distribution of the registers (genres) identified by Parodi (2010a) in four different disciplines.

What's the significance of Parodi's (2010e) findings interpreted in systemic functional terms? The characterizations of Textbooks and Disciplinary Texts given by Parodi et al. (2010), quoted immediately above, strongly indicate that in terms of field of activity, Textbooks operate in 'expounding' contexts and Disciplinary Texts in 
'exploring' contexts. In other words, the four disciplines have different registerial centres of gravity, and the two physical disciplines (Construction Engineering, Industrial Chemistry) are very similar, as are the two non-physical ones (Psychology, Social Work). Didactic Guides (or Guidelines) occur mostly in Industrial Chemistry, and in terms of field of activity, they are 'enabling', more specifically 'instructing'. The relative frequencies provided by Parodi (2010a) are summarized in Table 6.

Table 6. Field of activity: expounding vs. exploring and favoured registers in the four university disciplines - Textbook (expounding) vs. Disciplinary Text (exploring).

\begin{tabular}{|l|l|l|l|l|l|}
\hline \multirow{2}{*}{$\begin{array}{l}\text { field of } \\
\text { activity }\end{array}$} & register & discipline & \multicolumn{2}{|l|}{} \\
\cline { 3 - 6 } & $\begin{array}{l}\text { Construction } \\
\text { Engineering }\end{array}$ & $\begin{array}{l}\text { Industrial } \\
\text { Chemistry }\end{array}$ & Psychology & $\begin{array}{l}\text { Social } \\
\text { Work }\end{array}$ \\
\hline expounding & Textbook & $\mathbf{7 1 . 0 \%}$ & $\mathbf{5 8 . 5 \%}$ & $13.7 \%$ & $10.6 \%$ \\
\hline exploring & $\begin{array}{l}\text { Disciplinary } \\
\text { Text }\end{array}$ & $10.1 \%$ & $0 \%$ & $\mathbf{6 4 . 3} \%$ & $\mathbf{8 3 . 0 \%}$ \\
\hline enabling & $\begin{array}{l}\text { Didactic } \\
\text { Guideline }\end{array}$ & $1.4 \%$ & $\mathbf{4 1 . 5 \%}$ & $7.9 \%$ & $0 \%$ \\
\hline
\end{tabular}

Thus in terms of field of activity within context, the key question is whether a discipline is primarily engaged in 'expounding' knowledge or 'exploring' issues (cf. Parodi, 2015). Let me add one observation at this point about the nature of disciplinary knowledge. The contributors to Parodi (2010a) don't discuss Bernstein's work, but I think it enhances the interpretation of their empirical findings.

In my understanding, Bernstein's (2000) distinction between vertical and horizontal knowledge structures can be correlated with the distinction between the 'expounding' field of activity and the 'exploring' field of activity. In 'expounding' contexts, texts are used to accumulate knowledge about some field of experience, developing it vertically on an initial foundation in the first year of study. This is what textbooks in Construction Engineering and Industrial Chemistry do. The texts are oriented towards building field, in Martin's (1993) sense.

In contrast, in 'exploring' contexts, texts are used go over essentially the same field of experience, comparing, contrasting, debating and arguing about different accounts (thus involving persuasion, as in the characterization of 'disciplinary text' quoted above). This is what disciplinary texts do in Psychology and Social Work. I remember Giovanni commenting sadly on one occasion that linguistics was probably like psychology and social work, tending to go over the same ground, arguing for successive theories. This seems very plausible to me as a grand generalization about the kind of linguistics that focussed on Chomsky's programme; but I suspect that SFL is much more like Construction Engineering and Industrial Chemistry. In SFL, building field is foregrounded, so a good deal of work is done in 'reporting' and 'expounding' contexts since the 'knowledge' created in these contexts is necessary before it becomes possible 
to explore different interpretations - especially in view of the holistic approach to theory in SFL and the value placed on comprehensive descriptions (cf. Halliday, 2014).

Let me sum up the points just made diagrammatically, referring again to field of activity (see Figure 4 above). Figure 10 shows textbooks as operating within 'expounding' contexts and disciplinary texts as operating within 'exploring' contexts. It also specifies the disciplines that favour either of these two fields of activity, and specifies the orientation of the knowledge being constructed within them.

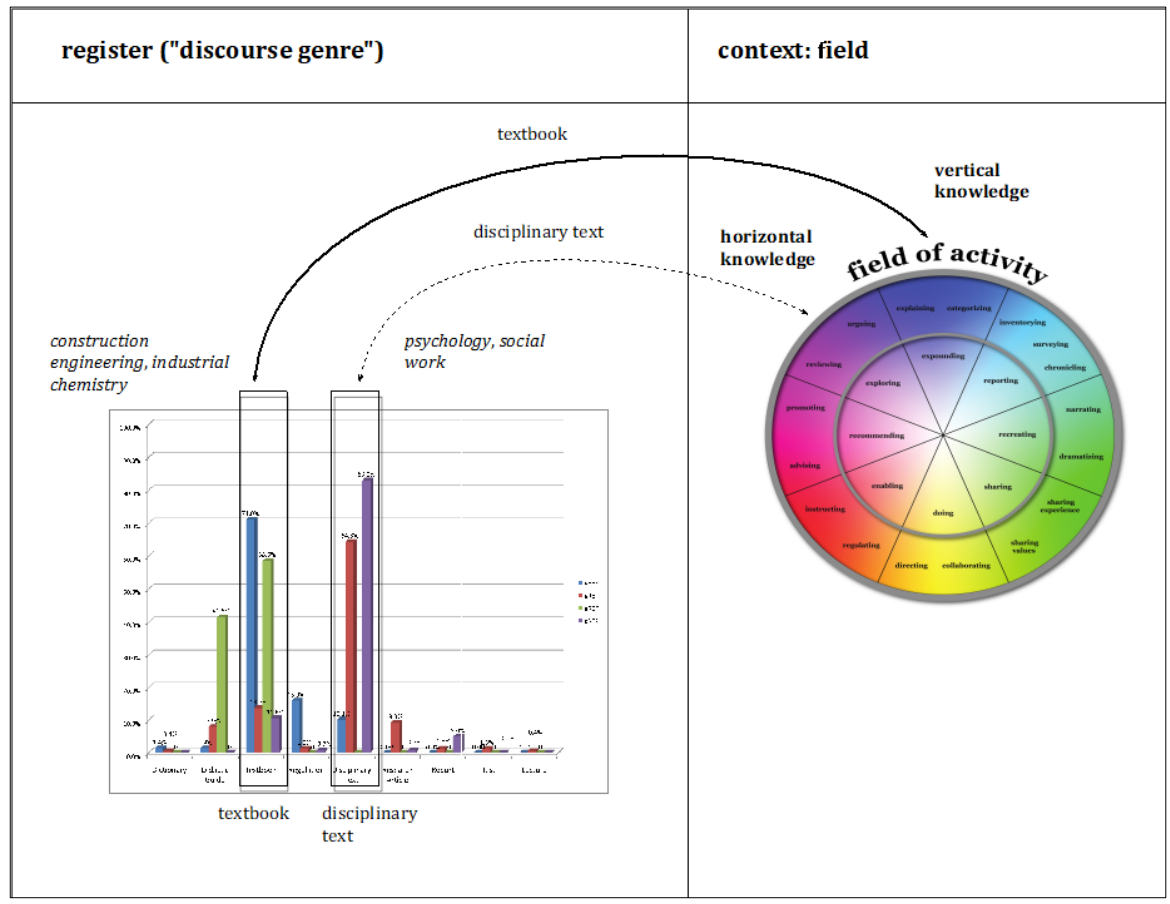

Figure 10. The two most frequent registers ('discourse genres') in the PUCV-2006 corpus differentiated in terms of fields of activity, with specifications of disciplines and orientation of knowledge structure (Bernstein).

Rounding off this section, let me suggest the distribution of registers, or 'discourse genres', identified by Parodi et al. (2010) in terms of the fields of activity within context set out in Figure 4, as I did for school subjects in Table 4. One difference is that the registers identified in the school subjects (e.g. by Christie \& Derewianka, 2008) are all instantiated as fairly short texts, perhaps no more than one page of writing; but while quite a few of the 'discourse genres' in the PUCV-2006 are similarly instantiated by short texts (like new reports, quotations, records, tests and certificates), many are macro-registers instantiated by quite long texts, like the most common ones, didactic texts and textbook. Macro-registers are often composite, with a nuclear register and other registers that support the nuclear register (cf. Martin, 1994). Not surprisingly, macro-registers can be hard to classify in terms of field of activity because the 
component registers may in fact operate in more than one. However, helpfully, Parodi et al. (2010: 51) identify the "macro-purpose" of each of the 29 "discourse genres" they characterize. For example, the macro-purpose of "medical order" is "The communicative macro-purpose of this discourse genre is to guide the execution of a medical procedure" and this characterization suggests that this discourse genre can be interpreting as operating in contexts where the field of activity is 'elaborating: instructing'. Nevertheless, the classification set out in Table 7 is tentative, and I have left out bidding specification, call for bid, memorandum, report and statement.

Table 7. Classification of the 'discourse genres' proposed by Parodi et al. (2010) in terms of field of activity.

\begin{tabular}{|l|l|l|}
\hline \multicolumn{2}{|l|}{ context } & language \\
\hline \multicolumn{2}{|l|}{ field of activity } & register (“discourse genre”) \\
\hline \multirow{2}{*}{ expounding } & explaining & textbook \\
\cline { 2 - 3 } & characterizing & dictionary \\
\hline \multirow{3}{*}{ reporting } & chronicling & news \\
\cline { 2 - 3 } & surveying & \\
\cline { 2 - 3 } & inventorying & medical report, quotation, record, test \\
\hline \multirow{2}{*}{ recreating } & narrating & \\
\cline { 2 - 3 } & dramatizing & \\
\hline \multirow{2}{*}{ sharing } & experiences & \\
\cline { 2 - 3 } & opinions & \\
\hline \multirow{2}{*}{ enabling } & directing & \\
\cline { 2 - 3 } & collaborating & \\
\cline { 2 - 3 } & regulating & certificate, law, regulation \\
\hline \multirow{2}{*}{ recommending } & instructing & calculation memory, development plan, medical order, observation \\
& guideline, operating manual, plan \\
\cline { 2 - 3 } & advising & \\
\hline \multirow{2}{*}{ exploring } & reviewing & brochure, commercial catalogue, research proposal \\
\cline { 2 - 3 } & rallying & \\
\cline { 2 - 3 } & arguing & disciplinary text, lecture, research article, thesis \\
\hline
\end{tabular}

In terms of the contextual parameter of field of activity, there are a number of gaps in the disciplinary registers ('discourse genres') identified and described by Parodi et al. (2010); but this is to be expected, and it reflects the strength of their disciplinary approach. It is easy to imagine that the study of other university disciplines along the same lines would add registers within certain fields of activity, e.g. the study of history and the study of literature. At the same time, we can also expect additional registers would be identified in the investigation of spoken language, of the kind represented in the MiCASE corpus, The Michigan Corpus of Academic Spoken English. ${ }^{13}$ However, to expand on the findings by Parodi (2010a) based on the PUCV-2006 Corpus, I will refer briefly to the 'genre families' across disciplines in the BAWE, British Academic Written English, Corpus - a corpus of student writing. 


\subsection{BAWE (British Academic Written English)}

Focussed on university student writing, Investigations of BAWE (e.g. Nesi \& Gardner, 2012) confirm the key findings about reading material in different disciplines reported by Parodi (2010a) that there is considerable registerial variation across university disciplines and also that physical sciences and non-physical sciences tend in fundamentally different directions. Alsop and Nesi (2009) describe the collection and compilation process (cf. also Heuboeck, Holmes \& Nesi, 2010). The corpus, from three universities, consists of student assignments from 35 disciplines, classified into four groupings, viz. arts and humanities, social sciences, life sciences, and physical sciences (cf. Table 5 above). The assignments come from three years of undergraduate students and from master's students, and total around 2,900 texts (around 6.5 million words).

Quite a range of registers, or 'genres', were identified, and Gardner and Nesi (2013) classify them into 13 families, building on the 'American tradition of classifying university student writing tasks' and 'the very different Australian tradition of classifying primary and secondary school children's written texts as genres' - i.e. the SFL work known as the 'Genre Model' (Martin \& Rose, 2008). Heuboeck et al. (2010: 7) present the distribution of the genre families across the disciplinary groupings, and also across the disciplines of each grouping. I have represented the counts in their "Table 3. Distribution of GFs [genre families, CMIMM] by DG [disciplinary grouping]" as a chart to make it easy to determine the registerial profiles of each disciplinary grouping: see Figure 11.

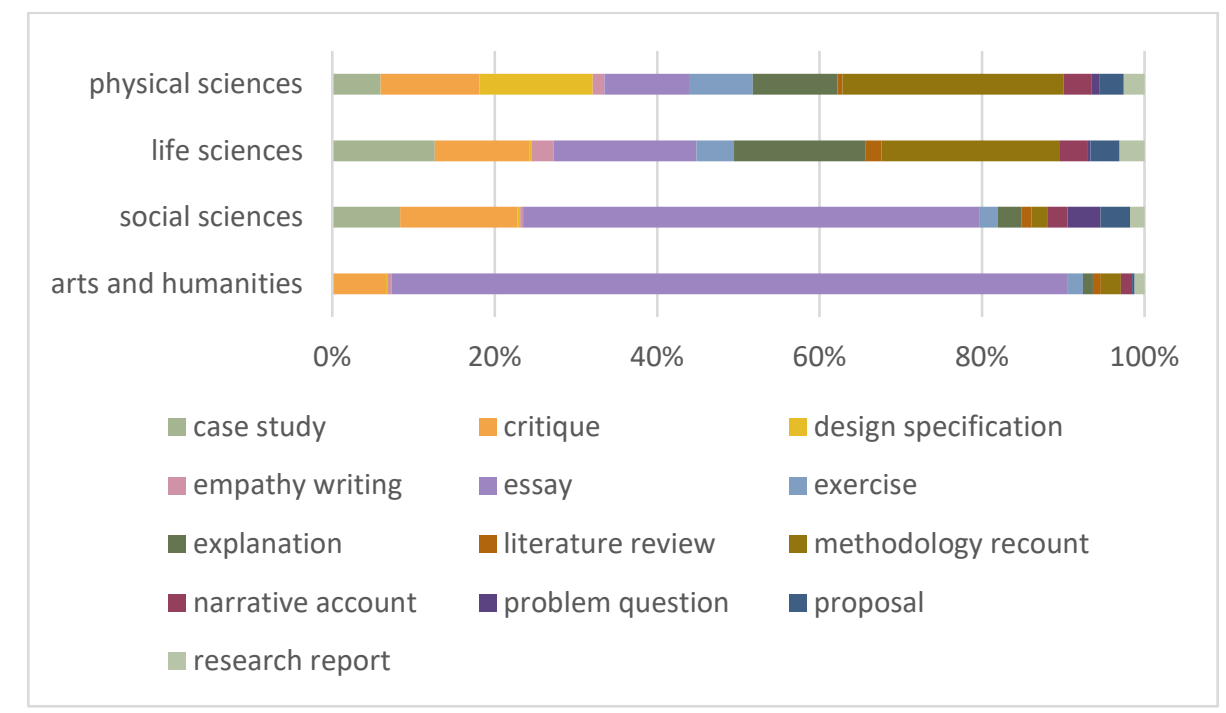

Figure 11. Chart showing distribution registers ('genre families') across four disciplinary areas, based on Heuboeck et al. (2010: 8) "Table 3. Distribution of GFs [genre families] by DG [disciplinary grouping]". 
As Figure 11 shows, arts \& humanities and social sciences differ from life sciences and physical sciences in that both their registerial profiles are dominated by the "essay" family. This family contains registers operating in contexts characterized by 'exploring' fields of activity; Nesi and Gardner (2012) include exposition, discussion and challenge (cf. Table 4 for these registers in school subjects). The essay family is much less prominent in life sciences and physical sciences, where the family of 'methodology recount', which includes lab reports and design reports, plays a significant role. In contrast, this family plays only a minor role in arts \& humanities and in social sciences - not surprisingly, since it is associated with the experimental method. There are other noteworthy differences among the four registerial profiles; for instance, the family of 'case study' (e.g. company reports, accident reports) figures physical sciences, life sciences and social sciences but not in arts \& humanities. However, the difference in the distribution of essays and of methodological recounts can be seen as representative of the discursive construction of the different discipline groupings in student writing. Essays can be compared to disciplinary texts in Parodi (2010a) - both operate in 'exploring' contexts where writers argue, trying to persuade their readers of some view. Methodological recounts reflect the same orientation towards scholarship as textbooks in Parodi (2010a). While students read textbooks, they don't write them; but they attend to related aspects of doing science.

\section{CONCLUSION}

In this paper, I have tried to indicate that the research in SFL into the registerial profiles of different school subjects and the research profile different university disciplines emerging from the research undertaken by Giovanni Parodi and his team (Parodi, 2010a) enable us to imagine learner paths from primary school through undergraduate programmes. The picture is necessarily sketchy, with many gaps in fields of experience as they are construed in the full range of school subjects and the full range of university disciplines; and the two traditions of research are based on different bodies of writing — writing by students in schools (although many 'model texts' have been analysed as well, as in Martin \& Rose, 2008) and readings assigned to students in tertiary education. It is, of course, to be expected that students must read texts in a much wider registerial range than they are expected to produce instances of in their own writing. Nevertheless, there is a consistent motif of registerial profiles of areas of studies that reflect the orientation of the subjects and disciplines students engage with as learners.

In terms of lifelong ontogenesis as depicted in Figure 1, I have focussed on the periods when children, adolescents and young adults learn in structured ways in institutions of formal education — schools and universities. Pre-school learning is obviously crucial, and as Halliday (2003) and Painter (1999) have demonstrated, the 
processes of learning during this period also involve both learning language (learning how to mean) and learning through language (learning content, i.e. fields of experience, through language as a resources for learning) - and also learning about language (i.e. language as a field of experience), as emphasized by Halliday (1993). This pre-school learning is oriented towards folk models, or commonsense knowledge, and it is then gradually replaced by, or supplemented by, uncommonsense knowledge, beginning with educational versions of scientific knowledge. It is when commonsense knowledge is gradually replaced by uncommonsense knowledge that learning begins to take place in increasingly subject-specific registers. The construction of commonsense knowledge is contextually fairly opportunistic, often spliced into casual conversations in contexts of sharing, e.g. during meals, as illustrated by examples provided by Halliday (1984) and Painter (1999).

As learners move through the educational system, subjects split into increasingly more specialized ones, and then into the disciplines of tertiary education. To a certain extent, this recapitulates what happened historically, as philosophy was split into increasingly scientific fields of study. This move of specialization is reflected in, and also created by, the increasing registerial specialization within different subjects and then disciplines. But different disciplines deal with different systemic orders of phenomenal realms, as indicated by the row headings in Table 5. These phenomenal realms are ordered into systems of increasing complexity (e.g. Halliday \& Matthiessen, 2006; Halliday, 2005; Matthiessen, 2007): physical < biological < social < semiotic; and the modern scientific study of these systemic orders progressed accordingly during the last 500 years or so: physical sciences $<$ biological sciences $<$ social sciences $<$ semiotic sciences. This clearly has fundamental implications for the study of the evolution of academic registers (Bazerman, 1988; Halliday, 1988; Swales, 1990) - and so also for students learning educational versions of these registers as the move through the educational system.

Parodi's view of knowledge constructed in university disciplines, shown in Figure 12, provides us with a gateway to the investigation of semiotic construction of disciplines as the study of different orders of phenomenal realms. His approach has implications for the continued investigation of registers in school subjects - centrally, the compilation of corpora comparable to the PUCV-2006 corpus. And at the same time, we need comparable corpora for school subjects and university disciplines covering both texts students are expected to read and texts they are assigned to write, and of course also complementary spoken registers. In addition, both systemic functional researcher and Parodi and his group have embarked on the study of semiotic systems other than language in various subjects and disciplines (in SFL, e.g. Doran, 2016) - a project Parodi reported on already at the International Systemic Functional Congress at the University of British Columbia in 2010. In other words, the gaps in the outline I have sketched here bringing together research by SFL scholars and by Parodi 
and his group need to be filled in - using complementary corpora such as BAWE (which has been informed by SFL, as in Gardner \& Nesi, 2013). The contributions in Parodi (2010a) also include registerial cartography of workplaces, the area to the right in Figure 1 - a hugely important contribution I have not been able to review here. Just as much more attention needs to be given to the transition from secondary to tertiary education, so much more attention needs to be given to the transition from tertiary education to workplaces, as the groundbreaking registerial cartography by Parodi (2010b) shows very clearly.

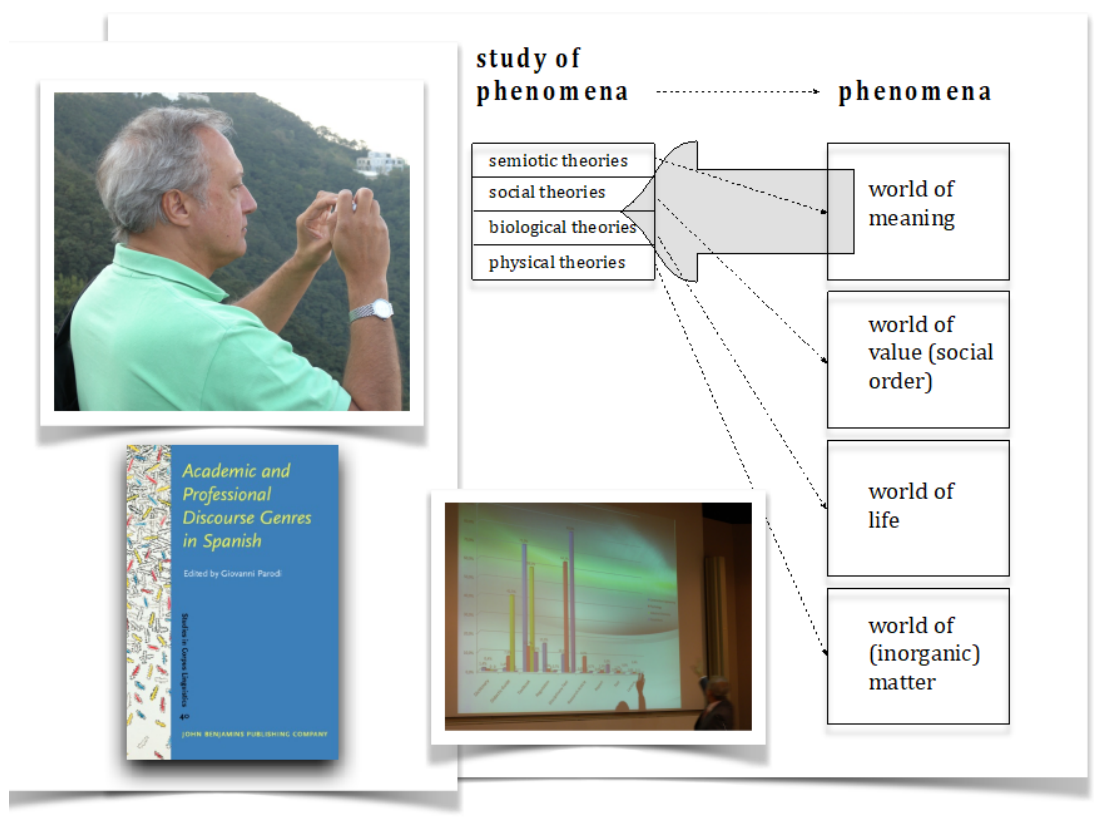

Figure 12. Parodi's view of 'discourse' genres, and the four orders of realms of phenomena and their fields of study.

\section{REFERENCES}

Alsop, S. \& Nesi, H. (2009). Issues in the development of the British Academic Written English (BAWE) corpus. Corpora, 4(1), 71-83.

Bazerman, C. (1988). Shaping written knowledge: The genre and activity of the experimental article in Science. Madison, WI: The University of Wisconsin Press.

Bernstein, B. (1971). Class, codes and control, Vol. 1: Theoretical Studies Towards a Sociology of Language. London: Routledge \& Kegan Paul. (Primary Socialization, Language and Education). 
Bernstein, B. (2000). Pedagogy, symbolic control and identity: Theory, research, critique. London: Rowan and Littlefield.

Bowcher, W. (2003). Speaker contributions in radio sports commentary. Text, 23(4), 445-476.

Bowcher, W. (2007). Field and multimodal texts. In R. Hasan, C.M.I.M. Matthiessen \& J. Webster (Eds.), Continuing Discourse on Language: A Functional Perspective, Volume 2 (pp. 619-646). London: Equinox.

Bowcher, W. (2014). Issues in developing unified systems for contextual field and mode. Functions of Language, 21(2), 176-209.

Byrnes, H. (2019). Applying SFL for Understanding and Fostering Instructed Second Language Development. In G. Thompson, W. L. Bowcher, L. Fontaine \& D. Schöntal (Eds.), The Cambridge Handbook of Systemic Functional Linguistics (pp. 512536). Cambridge: Cambridge University Press.

Byrnes, H., Maxim, H. \& Norris, J. (2010). Realizing advanced foreign language writing development in collegiate education: Curricular design, pedagogy, assessment. The Modern Language Journal, 94(4), 674.

Caldwell, D. (2014). The interpersonal voice: Applying appraisal to the rap and sung voice. Social Semiotic, 24(1), 40-55.

Christie, F. \& Beverley, D. (2008). School discourse: Learning to write across the years of schooling. London \& New York: Continuum.

Christie, F. \& J. R. Martin (Ed.) (1997). Genre and institutions: Socialprocesses in the workplace and school. London: Cassell.

Christie, F. \& Macken-Horarik, M. (2007). Building verticality in subject English. In F. Christie \& J. R. Martin (Eds.), Language, knowledge and pedagogy: functional linguistic and sociological perspectives (pp. 156-183). London \& New York: Continuum.

Christie, F. \& Derewianka, B. (2008). School discourse: Learning to write across the years of schooling. London \& New York: Continuum.

Coffin, C. (2006). Historical discourse. London \& New York: Continuum.

Derewianka, B. (1995). Language development in the transition from childhood to adolescence: The role of grammatical metaphor. Unpublished doctoral dissertation, Macquarie University, Sydney, Australia.

Doran, Y. J. (2016). Knowledge in Physics through Mathematics, Image and Language. Unpublished doctoral dissertation, Sydney University, Sydney, Australia.

Eggins, S. \& Slade, D. (2005). Analysing casual conversation. London: Equinox. 
Eggins, S., Wignell, P. \& Martin, J. R. (1987). The discourse of history: Distancing the recoverable past. In J. R. Martin, P. Wignell \& S. Eggins (Eds.), Writing Project Report 1987. Sydney: University of Sydney Linguistics Department.

French, R. (2013). Teaching and learning functional grammar in junior primary classrooms. Unpublished doctoral dissertation, University of New England, Armidale.

Gardner, S. (2017). Systemic functional linguistics and genre studies. In T. Bartlett \& G. O'Grady (Eds.), The Routledge handbook of systemic functional linguistics (pp. 473488). Milton Park: Routledge.

Gardner, S. \& Nesi, H. (2013). A Classification of Genre Families in University Student Writing. Applied Linguistics, 34(1), 25-52.

Gregory, M. J. (1967). Aspects of varieties differentiation. Journal of Linguistics, 3, 177 198.

Guerra-Lyons, J. (2021). Making Meaning Throughout Writing Trajectories: Towards a Social Semiotic Account of Language Change in Scholars' Theory Construction. Unpublished doctoral dissertation, The Hong Kong Polytechnic University, Hong Kong.

Guo, N. (2014). The ontogenesis of multiliteracy scaffolding in textbooks: Multimodal analysis of English Language Teaching textbooks of different grade. Unpublished doctoral dissertation, The Hong Kong Polytechnic University, Hong Kong.

Guo, N. \& Yao, Y. (in press). Language demands of textbooks for learning English in Hong Kong: A multi-stratal analysis. Linguistics and Education.

Halliday, M.A.K. (1972). Towards a sociological semantics. Working Papers and Prepublications (series C, no. 14). Università di Urbino: Centro Internazionale di Semiotica e di Linguistica.

Halliday, M.A.K. (1975). Learning how to mean: Explorations in the development of language. London: Edward Arnold.

Halliday, M.A.K. (1978). Language as social semiotic: The social interpretation of language and meaning. London: Edward Arnold.

Halliday, M.A.K. (1984). Listening to Nigel. Sydney University Linguistics Department. Mimeo. Published as part of M.A.K. Halliday (2003), The language of early childhood. Volume 4 of the Collected works of M.A.K. Halliday. Edited by Jonathan J. Webster. London \& New York: Continuum.

Halliday, M.A.K. (1988). On the language of physical science. In M. Ghadessy (Ed.), Registers of Written English: Situational factors and linguistic features (pp. 162-178). London \& New York: Pinter Publishers. 
Halliday, M.A.K. (1991). The notion of 'context' in language education. In T. Le \& M. McCausland (Ed.), Interaction and development: Proceedings of the international conference, Vietnam, 30 March - 1 April 1991 (pp. 1-26). University of Tasmania: Language Education.

Halliday, M.A.K. (1993). Towards a language-based theory of learning. Linguistics and Education, 5(2), 93-116.

Halliday, M.A.K. (1994). Language and the theory of codes. In A. Sadovnik (Ed.), Knowledge and pedagogy: The sociology of Basil Bernstein (pp. 124-142). Norwood, N.J.: Ablex.

Halliday, M.A.K. (2002). Computing meanings: Some reflections on past experience and present prospects. In G. Huang \& Z. Wang (Eds.), Discourse and Language Functions (pp. 3-25). Shanghai: Foreign Language Teaching and Research Press.

Halliday, M.A.K. (2003). The Language of Early Childhood. Volume 4 of Collected Works of M.A.K. Halliday. London \& New York: Continuum.

Halliday, M.A.K. (2005). On matter and meaning: The two realms of human experience. Linguistics and the Human Sciences, 1(1), 59-82.

Halliday, M.A.K. (2014). On Explanation in Systemic Functional Theory. Linguistics and Human Sciences, 10(1), 13-27.

Halliday, M.A.K. \& Hasan, R. (1985). Language, context and text: A social semiotic perspective. Geelong, Vic.: Deakin University Press.

Halliday, M.A.K. \& Matthiessen, C.M.I.M. (2006). Construing experience through meaning: A language-based approach to cognition. London \& New York: Continuum.

Halliday, M.A.K. \& Matthiessen, C.M.I.M. (2014). Halliday's introduction to functional grammar. Fourth Edition. London: Routledge.

Halliday, M.A.K., McIntosh, A. \& Strevens, P. (1964). The linguistic sciences and language teaching. London: Longman.

Hasan, R. (1973). Code, register and social dialect. In B. Bernstein (Ed.), Class, Codes and Control: Applied studies towards a sociology of language. Volume 2 (pp. 253-292). London: Routledge \& Kegan Paul.

Hasan, R. (1999). Speaking with reference to context. In M. Ghadessy (Ed.), Text and Context in Functional Linguistics: Systemic Perspectives (pp. 219-328). Amsterdam \& Philadelphia: John Benjamins. 
Hasan, R. (2009). Semantic Variation: Meaning in Society and Sociolinguistics. Volume 2. The Collected Works of Ruqaiya Hasan, edited by Jonathan Webster. London: Equinox.

Heuboeck, A., Holmes, J. \& Nesi, H. (2010). The BAWE Corpus Manual for the project entitled "An investigation of genres of assessed writing in British Higher Education". Version III (June 2010) [on line]. Retrieved from: https://www.coventry.ac.uk/globalassets/media/global/08-new-researchsection/current-projects/bawemanual-v3.pdf

Iedema, R., Feez, S. \& White, P. (1994). Media literacy. (Write it right industry research report no. 2.) Sydney: NSW, Department of Education, Disadvantaged Schools Program Metropolitan East.

Knain, E. (2015). Scientific literary for participation: A systemic functional approach to analysis of school science discourses. Rotterdam: Sense Publishers.

Lukin, A. (2003). Examining poetry: A corpus based enquiry into literary criticism. Unpublished doctoral dissertation, Macquarie University, Sydney, Australia.

McCabe, A. (2021). A Functional Linguistic Perspective on Developing Language. London: Routledge.

Macken-Horarik, M. (2006). Recognizing and realizing 'what counts' in examination English: Perspectives from systemic functional linguistics and code theory. Functions of Language, 13(1), 1-35.

Martin, J. R. (1985). Factual writing: Exploring and challenging social reality. Geelong, Victoria: Deakin University Press.

Martin, J. R. (1992). English Text: System and structure. Amsterdam: John Benjamins.

Martin, J. R. (1993). Life as a Noun. In M.A.K. Halliday \& J. R. Martin (Eds.), Writing Science: Literacy and Discursive Power (pp. 221-267). London: Falmer.

Martin, J. R. (1994). Macro-genres: The ecology of the page. Network, 21, 29-52.

Martin, J. R. \& Matthiessen, C.M.I.M. (1991). Systemic typology and topology. In F. Christie (Ed.), Literacy in social processes: Papers from the Inangural Australian Systemic Functional Linguistics Conference, Deakin University, January 1990 (345-383). Darwin: Centre for Studies of Language in Education, Northern Territory University.

Martin, J. R. \& Rose, D. (2008). Genre relations: Mapping culture. London \& Oakville: Equinox. 
Martin, J. R. \& Wodak, R. (Eds.) (2003). Re/Reading the Past: Critical and Functional Perspectives on Time and Value (Discourse Approaches to Politics, Society and Culture, 8). Amsterdam \& Philadelphia: John Benjamins.

Martinec, R. (2018). Linguistic rhythm and its meaning: Rhythm waves and semantics fields. Linguistics and the Human Sciences, 14(1-2), 70-98.

Matthiessen, C.M.I.M. (1993). Register in the round: diversity in a unified theory of register analysis. In M. Ghadessy (Ed.), Register analysis: Theory and practice (pp. 221-292). London: Pinter.

Matthiessen, C.M.I.M. (2006). The multimodal page: a systemic functional exploration. In T. D. Royce \& W. Bowcher (Eds.), New Directions in the Analysis of Multimodal Discourse (pp. 1-62). Hillsdale, NJ: Lawrence Erlbaum.

Matthiessen, C.M.I.M. (2007). The "architecture" of language according to systemic functional theory: developments since the 1970s. In R. Hasan, C.M.I.M. Matthiessen \& J. Webster (Eds.), Continuing discourse on language. Volume 2. (pp. 505-561). London: Equinox.

Matthiessen, C.M.I.M. (2009). Multisemiotic and context-based register typology: Registerial variation in the complementarity of semiotic systems. In E. Ventola \& A. J. Moya (Eds.), The world shown and the world told (pp. 11-38). Basingstoke: Palgrave Macmillan.

Matthiessen, C.M.I.M. (2014). Talking and writing about literature: Some observations based on systemic functional linguistics. The Indian Journal of Applied Linguistics, 39(2), 5-49.

Matthiessen, C.M.I.M. (2015a). Register in the round: Registerial cartography. Functional Linguistics, 2(9), 1-48.

Matthiessen, C.M.I.M. (2015b). Modelling context and register: The long-term project of registerial cartography. Estudos sistêmico-funcionais: Desdobramentos e interfaces. Revista Letras, Santa Maria, 50, 15-90.

Matthiessen, C.M.I.M. (2015c). Subliminal construal of world order clause by clause: Hierarchy of control in Noah's Ark." Linguistics and the Human Sciences, 11(1-2), 250-283.

Matthiessen, C.M.I.M. (2018). The notion of a multilingual meaning potential: A systemic exploration. In A. Baklouti \& L. Fontaine (Eds.), Perspectives from Systemic Functional Linguistics (pp. 90-120). London: Routledge. Chapter 6.

Matthiessen, C.M.I.M. (2019). Register in Systemic Functional Linguistics. Register Studies, 1(1),10-41. 
Matthiessen, C.M.I.M. (in press). System in Systemic Functional Linguistics: A system-based theory of language. Sheffield: Equinox.

Matthiessen, C.M.I.M. \& Pun, J. (2019). Expounding knowledge through explanations: Generic types and rhetorical-relational patterns. Semiotica: Journal of the International Association for Semiotic Studies / Revue de l Association Internationale de Sémiotique, 227, 31-76.

Matthiessen, C.M.I.M. \& Teruya K. (2016). Registerial hybridity: Indeterminacy among fields of activity. In D. Miller \& P. Bayley (Eds.), Permeable contexts and bybrid discourses (pp. 205-239). London: Equinox.

Matthiessen, C.M.I.M. \& Teruya, K. (Forthcoming). Guide to Systemic Functional Linguistics. London: Routledge.

Montemayor-Borsinger, A. (2003). A comparison of Thematic options in novice and expert research writing. Estudios de Lingüistica Aplicada, 37, 37-51.

Nanri, K. (1993). An attempt to synthesize two systemic contextual theories through the investigation of the process of the evolution of the discourse semantic structure of the newspaper reporting article. Unpublished doctoral dissertation, University of Sydney, Sydney, Australia.

Nesi, H. \& Gardner, S. (Eds.) (2012). Genres across the disciplines: Student writing in higher education. Cambridge: Cambridge University Press.

O’Halloran, K. L. (2005). Mathematical Discourse: Language, Symbolism and Visual Images. London \& New York: Continuum.

Painter, C. (1984). Into the mother tongue: A case study in early language development. London: Frances Pinter.

Painter, C. (1999). Learning through language in early childhood. London: Cassell.

Painter, C. (2017). Learning how to mean: Parent-child interaction. In T. Bartlett \& G. O’Grady (Eds.), The Routledge handbook of systemic functional linguistics (pp. 619633). Milton Park: Routledge.

Parodi, G.(Ed.) (2010a). Academic and professional discourse genres in Spanish. Amsterdam: John Benjamins.

Parodi, G. (2010b). Discourse genres, academic and professional discourses: The book and its contents. In G. Parodi (Ed.), Academic and professional discourse genres in Spanish (pp. 7-16). Amsterdam: John Benjamins. 
Parodi, G. (2010c). Written discourse genres: Towards an integral conception from a sociocognitive perspective. In G. Parodi (Ed.), Academic and professional discourse genres in Spanish (pp. 17-35). Amsterdam: John Benjamins.

Parodi, G. (2010d). Academic and professional genres: Variations across disciplines. In G. Parodi (Ed.), Academic and professional discourse genres in Spanish (pp. 6582). Amsterdam: John Benjamins.

Parodi, G. (2010e). University academic genres: A miscellaneous discourse. In G. Parodi (Ed.), Academic and professional discourse genres in Spanish (pp. 83-99). Amsterdam: John Benjamins.

Parodi, G. (2010f). The Textbook genre and its rhetorical organisation in four scientific disciplines: Between abstraction and concreteness. In G. Parodi (Ed.), Academic and professional discourse genres in Spanish (pp. 171-187). Amsterdam: John Benjamins.

Parodi, G. (2015). Variation across university genres in seven disciplines: A corpusbased study on academic written Spanish. International Journal of Corpus Linguistics, 20(4), 469-499.

Parodi, G., Ibáñez, R. \& Venegas, R. (2010). Discourse genres in the PUCV-2006 academic and professional corpus of Spanish: Criteria, definitions, and examples. In G. Parodi (Ed.), Academic and professional discourse genres in Spanish (pp. 37-63). Amsterdam: John Benjamins.

Patten, T. (1988). Systemic text generation as problem solving. Cambridge: Cambridge University Press.

Pun, K. H. (2011). Analysis of Hong Kong science textbooks using systemic functional approach. Unpublished Master Thesis, Department of English, Hong Kong Polytechnic University, Hong Kong.

Rose, D. \& Martin, J. R. (2012). Learning to Write, Reading to Learn: Genre, Knowledge and Pedagogy in the Sydney School. (Equinox Textbooks \& Surveys in Linguistics). London: Equinox.

Schleppegrell, M. (2004). The Language of Schooling: A functional linguistics approach. Mahwah, NJ: Lawrence Erlbaum.

Slade, D., Manidis, M., McGregor, J., Scheeres, H., Chandler, E., Stein-Parbury, J., Dunstan, R., Herke, M. \& Matthiessen, C.M.I.M. (2015). Communication in Hospital Emergency Departments. Berlin: Springer.

Swales, J. (1990). Genre analysis: English in an academic research setting. Cambridge: Cambridge University Press. 
Teich, E., Degaetano-Ortlieb, S., Fankhauser, P., Kermes, H. \& Lapshinova-Koltunski, E. (2016). The Linguistic Construal of Disciplinarity: A Data-Mining Approach Using Register Features. Journal of the Association for Information Science and Technology, 67(7), 1668-1678.

Torr, J. (1997). From child tongue to mother tongue: A case study of language development in the first two and a half years. University of Nottingham: Monographs in systemic linguistics, Number 9.

Torr, J. (2015). Language development in early childhood: learning how to mean. In J. Webster (Ed.), The Bloomsbury Companion to M.A.K. Halliday (pp. 242-256). London: Bloomsbury Academic.

Unsworth, L. (1995). How and why: Recontextualizing science explanations in school science books. Unpublished doctoral dissertation, University of Sydney, Sydney, Australia.

Ure, J. N. \& Ellis, J. (1977). Register in descriptive linguistics and linguistic sociology. In O. Uribe-Villegas (Ed.), Issues in Sociolinguistics (pp. 197-243). The Hague: Mouton.

Veel, R. (1997). Learning how to mean - scientifically speaking: Apprenticeship into scientific discourse in the secondary school. In F. Christie \& J. R. Martin (Eds.), Genre and institutions: Social processes in the workplace and school (pp. 161-195). London: Cassell.

Wegener, R. (2011). Parameters of context: From theory to model and application. Unpublished doctoral dissertation, Macquarie University, Sydney, Australia.

Wignell, P. (1994). Genre across the curriculum. Linguistics and Education, 6(4), 355-372.

Wignell, P. (2007). On the discourse of social science. Darwin: Charles Darwin University Press.

Wignell, P., Martin, J. R. \& Eggins, S. (1987). The discourse of geography: Ordering and explaining the experiential world. Working papers in Linguistics 5 - Writing project Report 1987 (pp. 66-116). Sydney: Department of Linguistics, University of Sydney.

Williams, G. (2005). Grammatics in schools. In R. Hasan, C.M.I.M. Matthiessen \& J. Webster (Eds.), Continuing Discourse on Language: A Functional Perspective, Volume 1 (pp. 281-310). London: Equinox.

Xuan, W. (2015). A longitudinal study of Chinese high school students learning English based on systemic functional text analysis. Unpublished doctoral dissertation, the Hong Kong Polytechnic University, Hong Kong. 
Xuan, W. \& Huang, X. (2017). Understanding interpersonal meaning-making in Chinese high school students' ESL writing: A systemic functional perspective. The Asian Pacific Education Researcher, 26, 227-238.

\section{NOTES}

${ }^{1}$ Since we first met in Chile in 2006, Giovanni Parodi and I have had many discussions dealing with his work on discourse genres and related research and my worn in registerial cartography and other aspects of Systemic Functional Linguistics. He kindly invited me to give intensive courses/ workshops on my work at PUCV on a number of occasions, and these extended visits gave us excellent opportunities to exchange ideas, enabling me to understand and draw on his pioneering research.

2 Both 'genre' and 'registers' have been used as terms with different senses in different traditions and schools and linguistics and other disciplines concerned with text (discourse). For discussion of the theoretical differences between Martin's (e.g. 1992) 'genre model' and the approach to register in the sense of functional variety, see e.g. Matthiessen $(2015 b, 2019)$ and Matthiessen and Teruya (forthcoming). The 'discourse genres' presented in Parodi (2010a) are all carefully defined, and based on the definitions and examples provided I can interpret them as registers associated with particular contextual values, in particular field of activity within context.

${ }^{3}$ For pioneering systemic functional studies of ontogenesis beyond formal education, in the course of academic lives, see Montemayor-Borsinger (2003) and Guerra-Lyons (2021).

4 This angle of vision is based on Michael Halliday's notion of trinocular vision (e.g. Halliday, 1978; Matthiessen, 2007; Halliday \& Matthiessen, 2014). 'From above' can be compared to the general notion of 'top-down', and 'from below' to 'bottom-up'. The third angle of vision, 'from roundabout', is missing in the top-down/ bottom-up framework, but it is essential in the study and theorization of semiotic systems. Applied to the investigation of register, 'from roundabout' means the study of registers at the stratum of semantics, 'from above' means the investigation of registers from the point of view of context, and 'from below' is the study of registers from the point of view of lexicogrammar, and by another step phonology or graphology. This is the notion of 'register in the round' put forward also in Matthiessen (1993, 2015a, 2019).

${ }^{5}$ In approaches to register where the automatic computational analysis characteristic of corpus linguistics has been used, as in the work by Douglas Biber and his colleagues, the view 'from below' has quite naturally been foregrounded since we can still only automate the analysis of fairly low-level patterns; and the same applies to studies in SFL based on computational analysis, e.g. Teich et al. (2016).

${ }^{6} \mathrm{We}$ are, of course, living through a period in semiotic history characterized by rapid innovations in semiotic technologies (i.e. technologies in the service of semiosis, like the Internet underpinning the World Wide Web and mobile technologies). These innovations are comparable to the introduction of the printing press, which also brought about far-reaching and rapid semiotic changes, although at a much more modest speed. In the first instance, these 
technological innovations are focussed on one area of context, viz. channel within the mode parameter, and particular platforms such as Facebook and Twitter can be designed and evolve to provide the environment for registers with different settings not only of mode, but also of the other contextual parameters, field and tenor.

${ }^{7}$ However, field of activity covers both semiotic processes and social ones; it is thus not restricted to 'communicative' processes. This is important in the characterizations of contexts that are primarily social, with semiotic contributions as an enabling motif, as in team sports, surgery, lab experiments, and other situations based on interactive behaviour that needs semiotic coordination or direction.

${ }^{8}$ Key studies were published in working papers already in the 1980s, including Eggins, Wignell and Martin (1987) on history, Wignell, Martin and Eggins (1987) on geography, and Martin et al. (1988) on 'secret English'. They have since been included in various edited volumes, but often with a considerable lag in time.

${ }^{9}$ They focus on subject English as mother tongue in the Australian school system. There is now a growing body of search in SFL concerned with second/ foreign language education adopting a view informed by register variation ('genre'), including Xuan (2015), Xuan and Huang (2017), Guo (2014), Guo and Yao (in press); Byrnes, Maxim and Norris (2010).

10 The classification presented in the table certainly needs further discussion; but here it's only used as a rough framework for comparison.

11 In systemic functional terms, these 'discourse genres' are described at a certain degree of delicacy, some categories being fairly broad like textbook and disciplinary text; but there is obviously variation within them (on the textbook genre), see Parodi, 2010f), and it would be possible to increase the delicacy to bring out this variation.

${ }^{12} \mathrm{I}$ 'm using the same terms as in the discussion of school subject above; I characterize both school subjects and university disciplines in terms of registerial profiles.

${ }^{13}$ https: / quod.lib.umich.edu/cgi/c/corpus / corpus?page $=$ home; $c=$ micase $; \mathrm{cc}=$ micase 